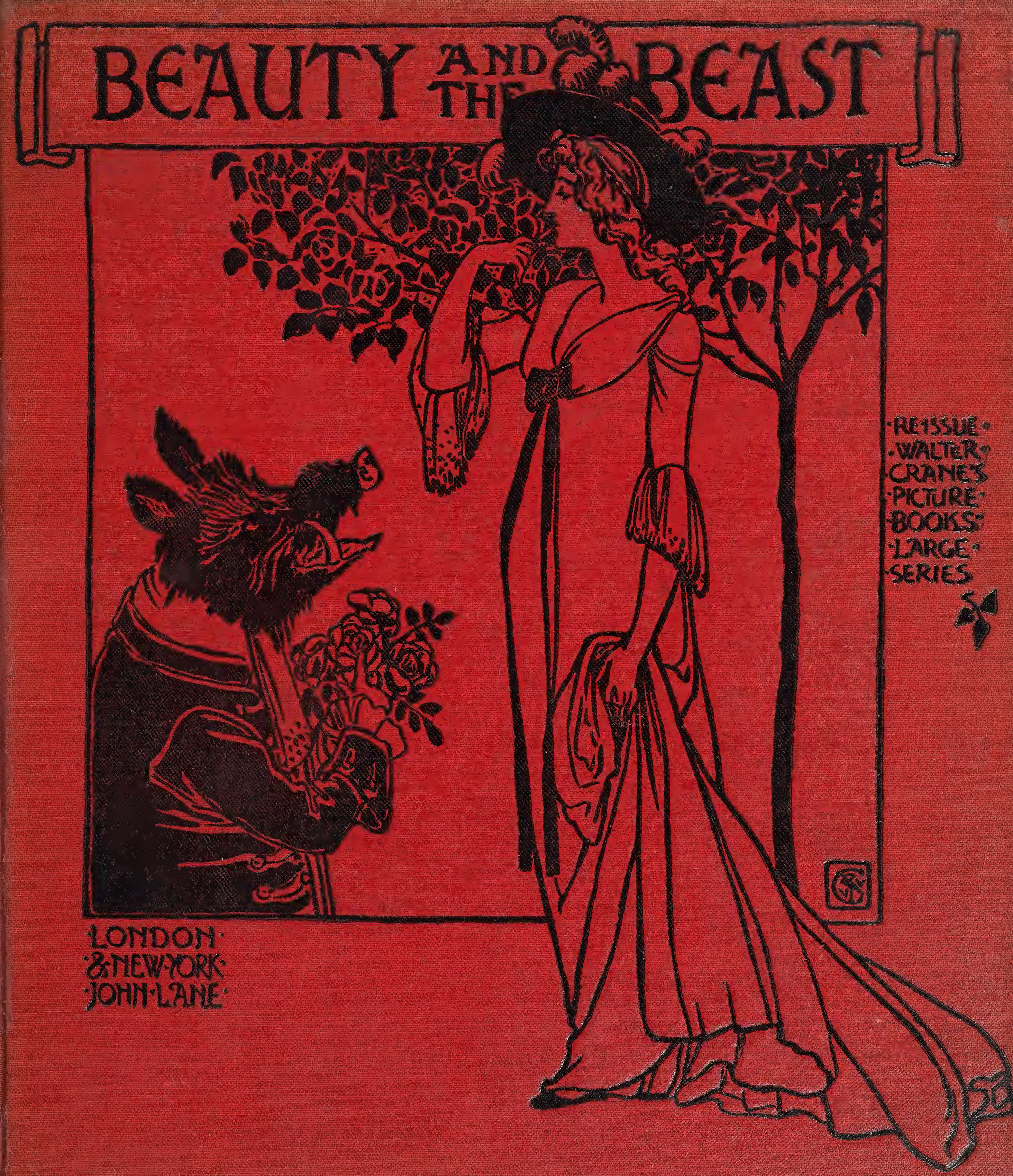




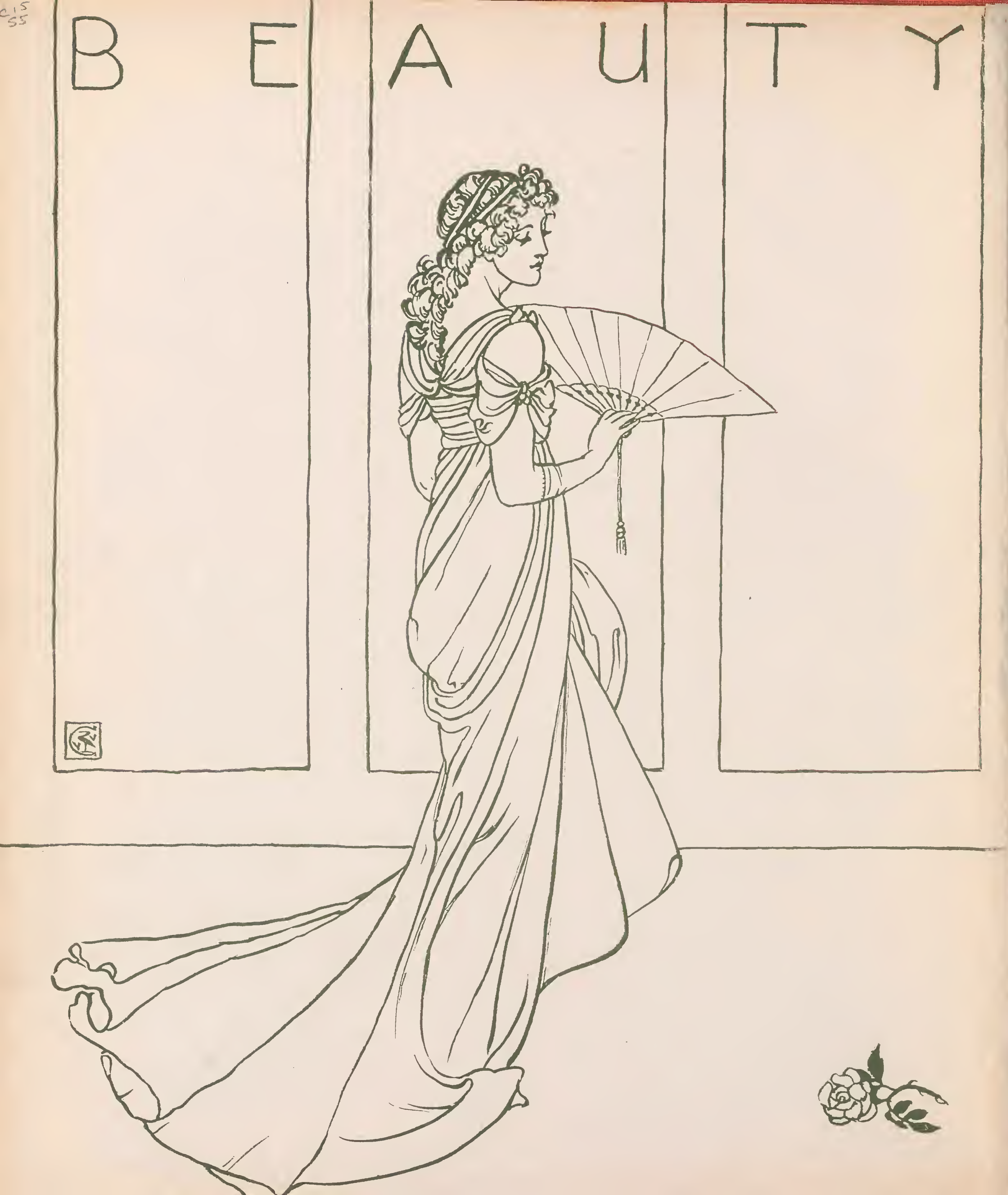






\section{BEAUTY AND THE BEAST.}

NCE upon a time a rich Merchant, meeting with heavy losses, had to retire to a small cottage, with his three daughters. The two elder grumbled at this; but the youngest, named Beauty, tried to comfort her father and make his home happy. Once, when he was going on a journey, to try to mend his fortunes, the girls came to wish him good-bye; the two elder told him to bring them some nice presents on his return, but Beauty merely begged of him to bring her a rose. When the Merchant was on his way back he saw some fine roses, and thinking of Beauty, plucked the prettiest he could find. He had no sooner taken it than he saw a hideous Beast, armed with a deadly weapon. This fierce-looking creature asked him how he dared to touch his flowers, and talked of putting him to death. The Merchant pleaded that he only took the rose to please his daughter Beauty, who had begged of him to get her one.

On this, the Beast said gruffly, "Well, I will not take your life, if you will bring one of your daughters here to die in your stead. She must come willingly, or I will not have her. You 


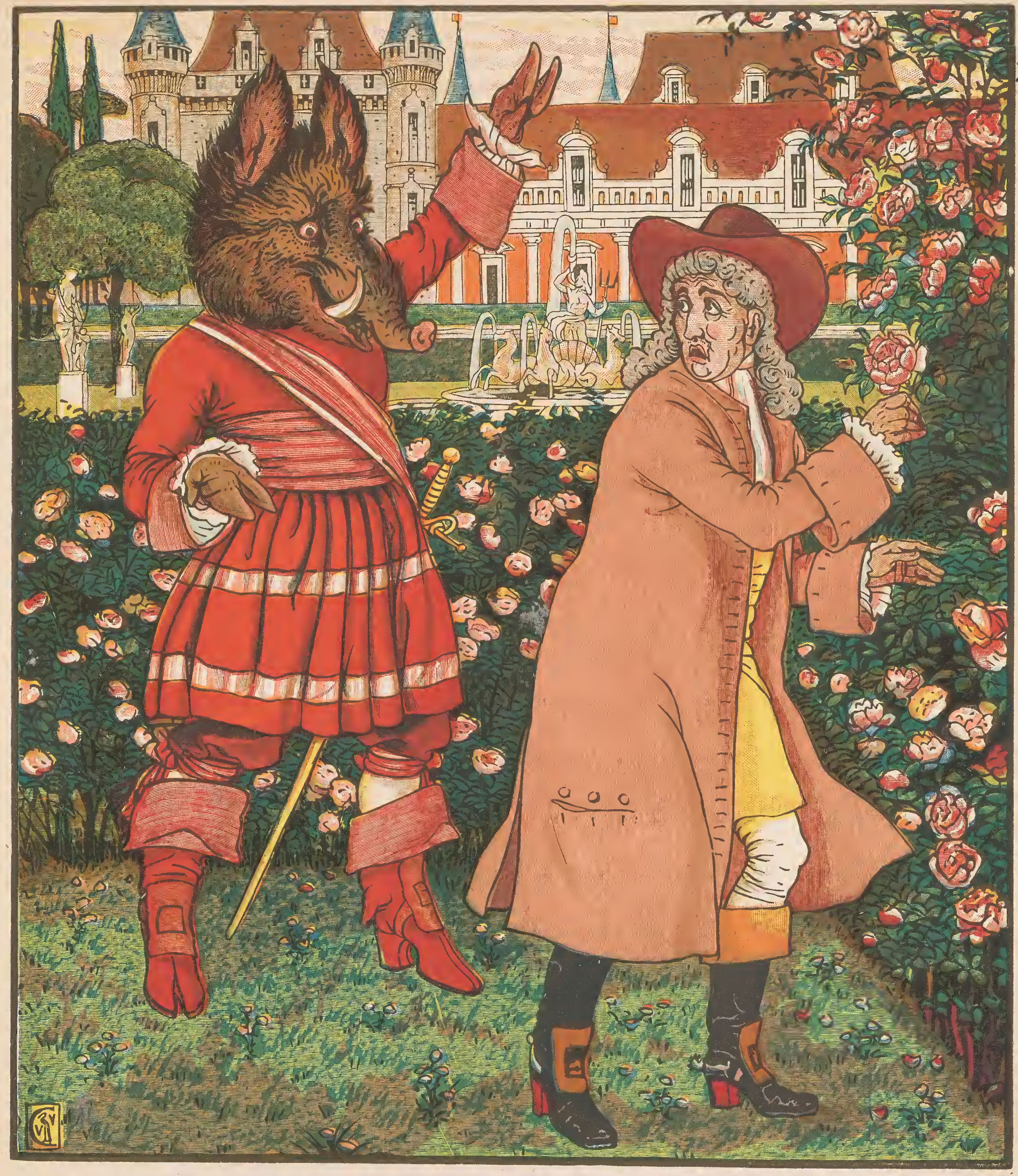



may stay and rest in my palace until to-morrow." Although the Merchant found an excellent supper laid for him, he could not eat; nor could he sleep, although everything was made ready for his comfort. The next morning he set out on a handsome horse, provided by the Beast.

When he came near his house his children came out to greet him. But seeing the sadness of his face, and his eyes filled with tears, they asked the cause of his trouble. Giving Beauty the rose, he told her all. The two elder sisters laid all the blame on Beauty; but his sons, who had come from the forest to meet him, declared that they would go to the Beast instead. But Beauty said that as she was the cause of this misfortune, she alone must suffer for it, and was quite willing to go; and, in spite of the entreaties of her brothers, who loved her dearly, she set out with her father, to the secret joy of her two envious sisters.

When they arrived at the palace the doors opened of themselves; sweet music was heard, and they walked into a room where supper was prepared. Just as they had eaten their supper, the Beast entered, and said in a mild tone, "Beauty, did you come here willingly to die in place of your father?" "Willingly," she answered, with a trembling voice. "So much the better for you," said the Beast; "your father 
can stay here to-night, but must go home on the following morning." Beauty tried to cheer her father, at parting, by saying that she would try to soften the heart of the Beast, and get him to let her return home soon. After he was gone, she went into a fine room, on the door of which was written, in letters of gold, "Beauty's Room;" and lying on the table was a portrait of herself, under which were these words: "Beauty is Queen here; all things will obey her." All her meals were served to the sound of music, and at supper-time the Beast, drawing the curtains aside, would walk in, and talk so pleasantly that she soon lost much of her fear of him. At last, he turned towards her, and said, "Am I so very ugly?" "Yes, indeed you are," replied Beauty, "but then you are so kind that I don't mind your looks." "Will you marry me, then?" asked he. Beauty, looking away, said, "Pray don't ask me." He then bade her "Good-night" with a sad voice, and she retired to her bed-chamber.

The palace was full of galleries and apartments, containing the most beautiful works of art. In one room was a cage filled with rare birds. Not far from this room she saw a numerous troop of monkeys of all sizes. They advanced to meet her, making her low bows. Beauty was much pleased with them, and said 


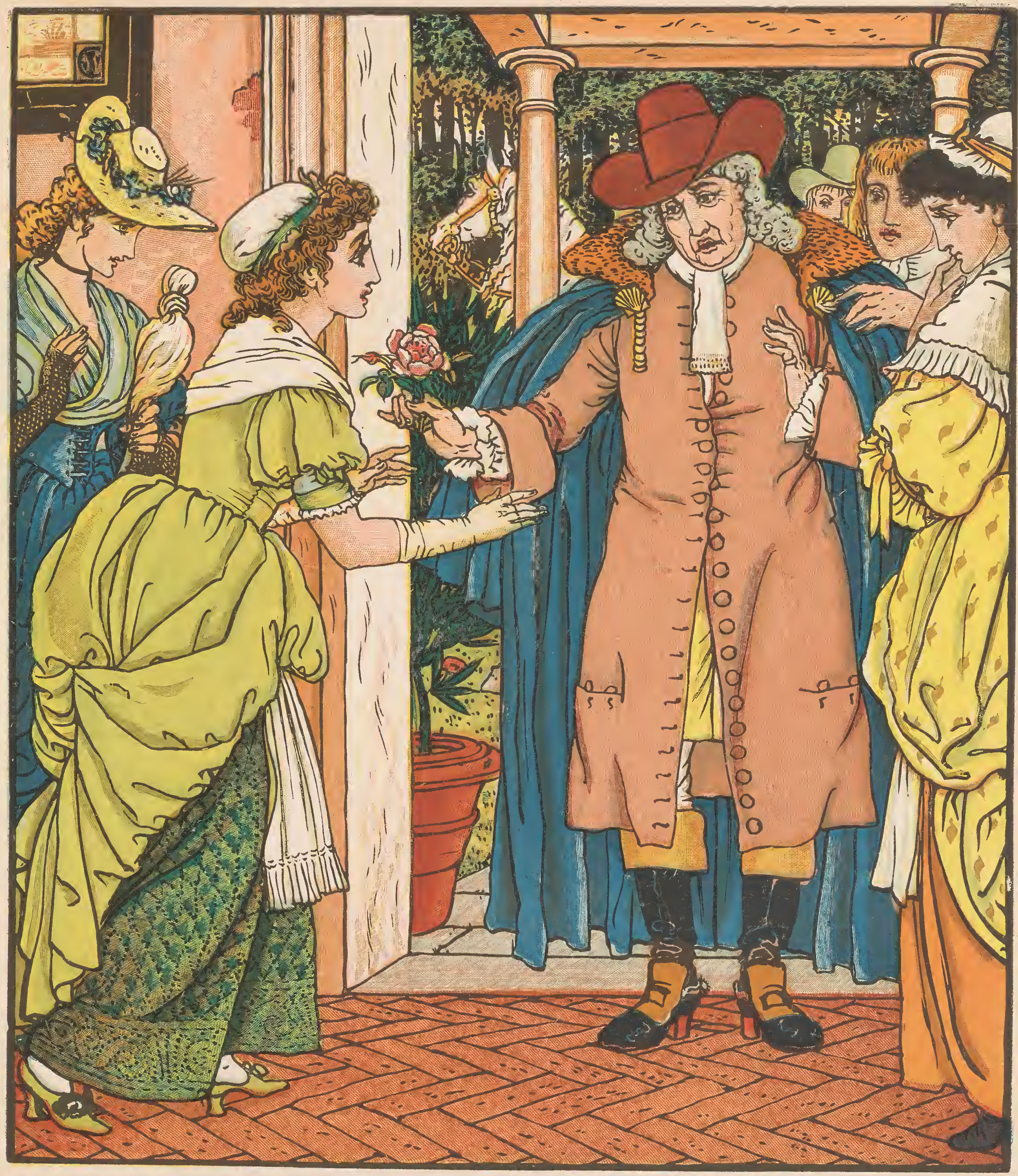





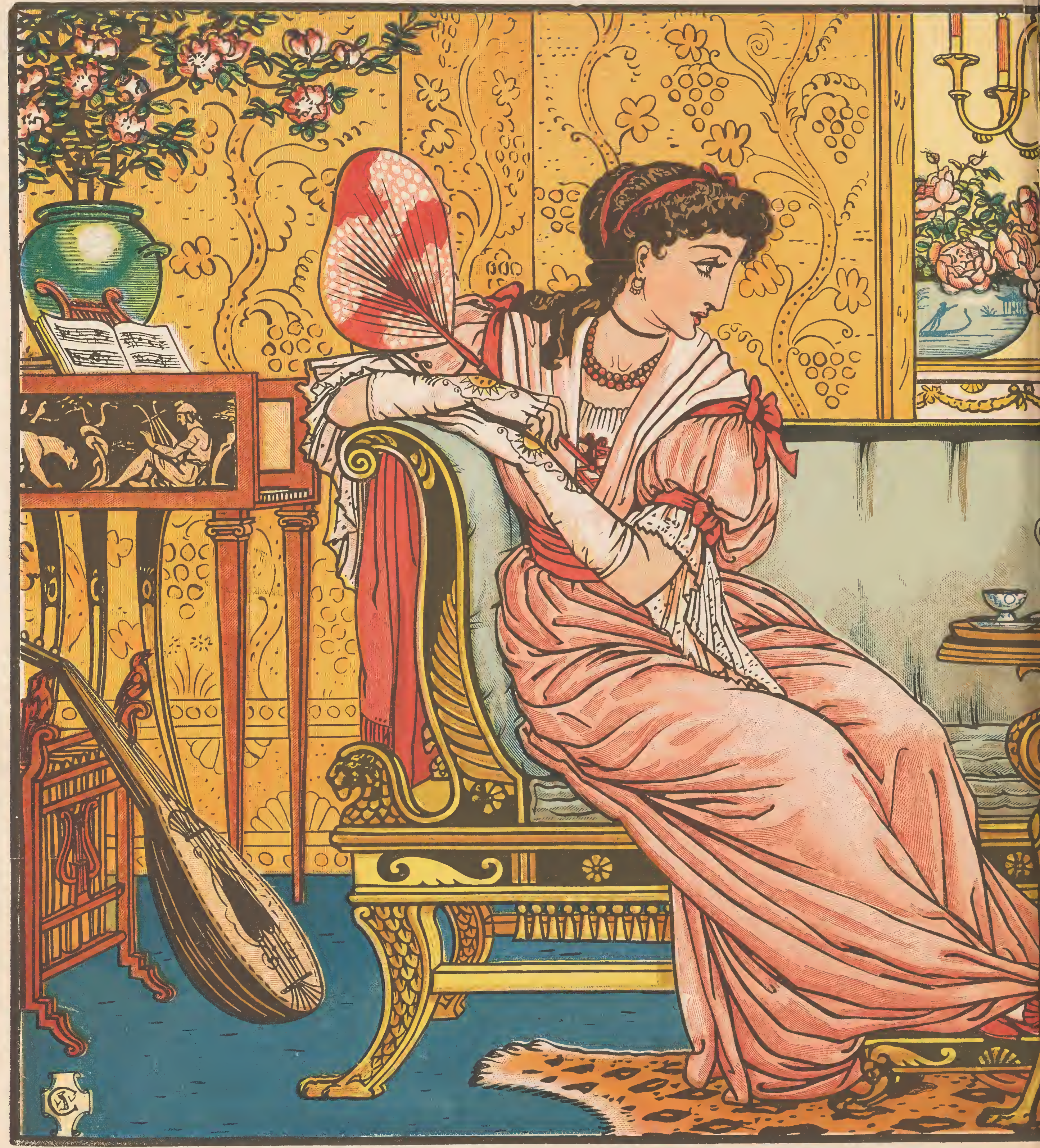




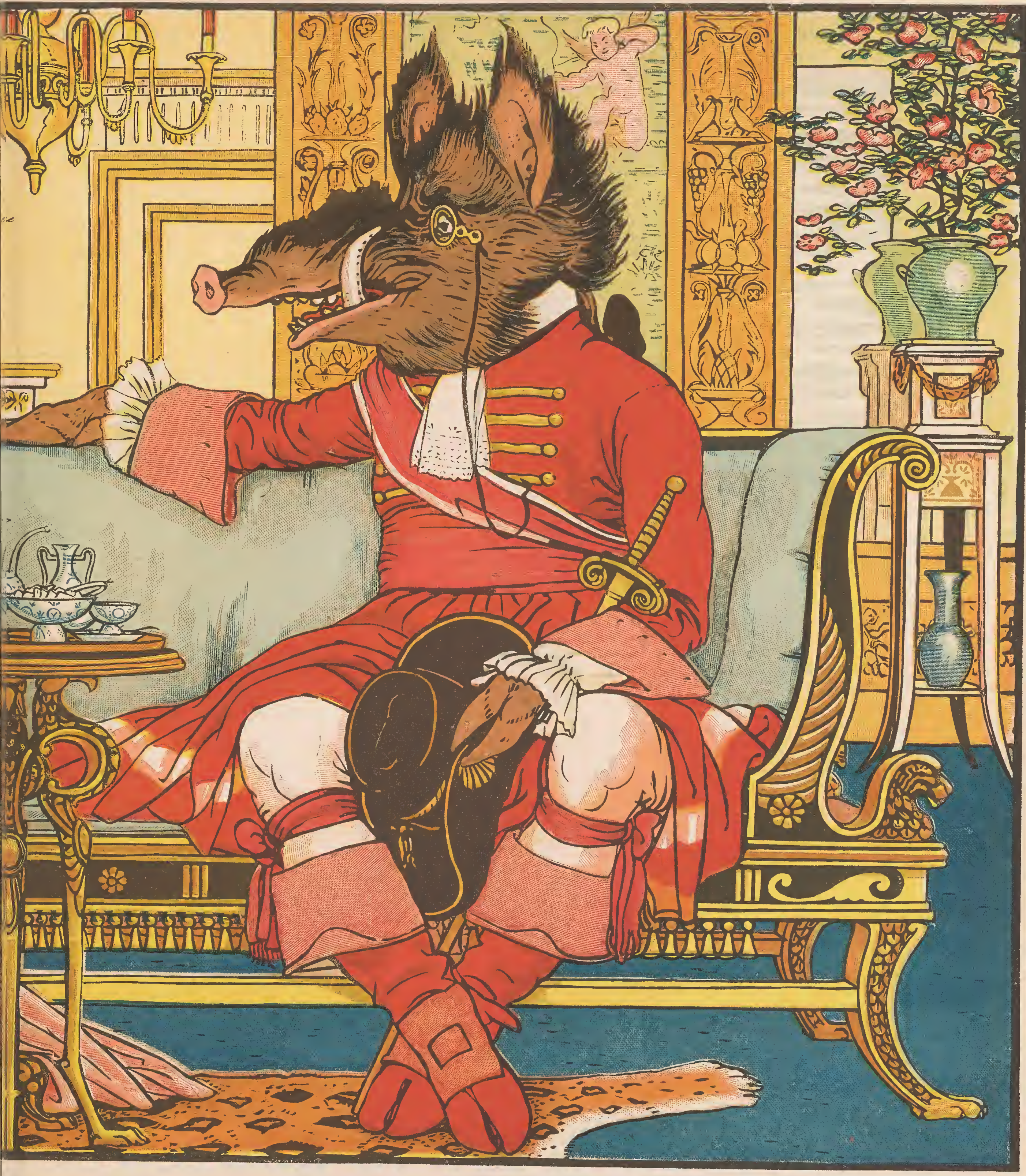





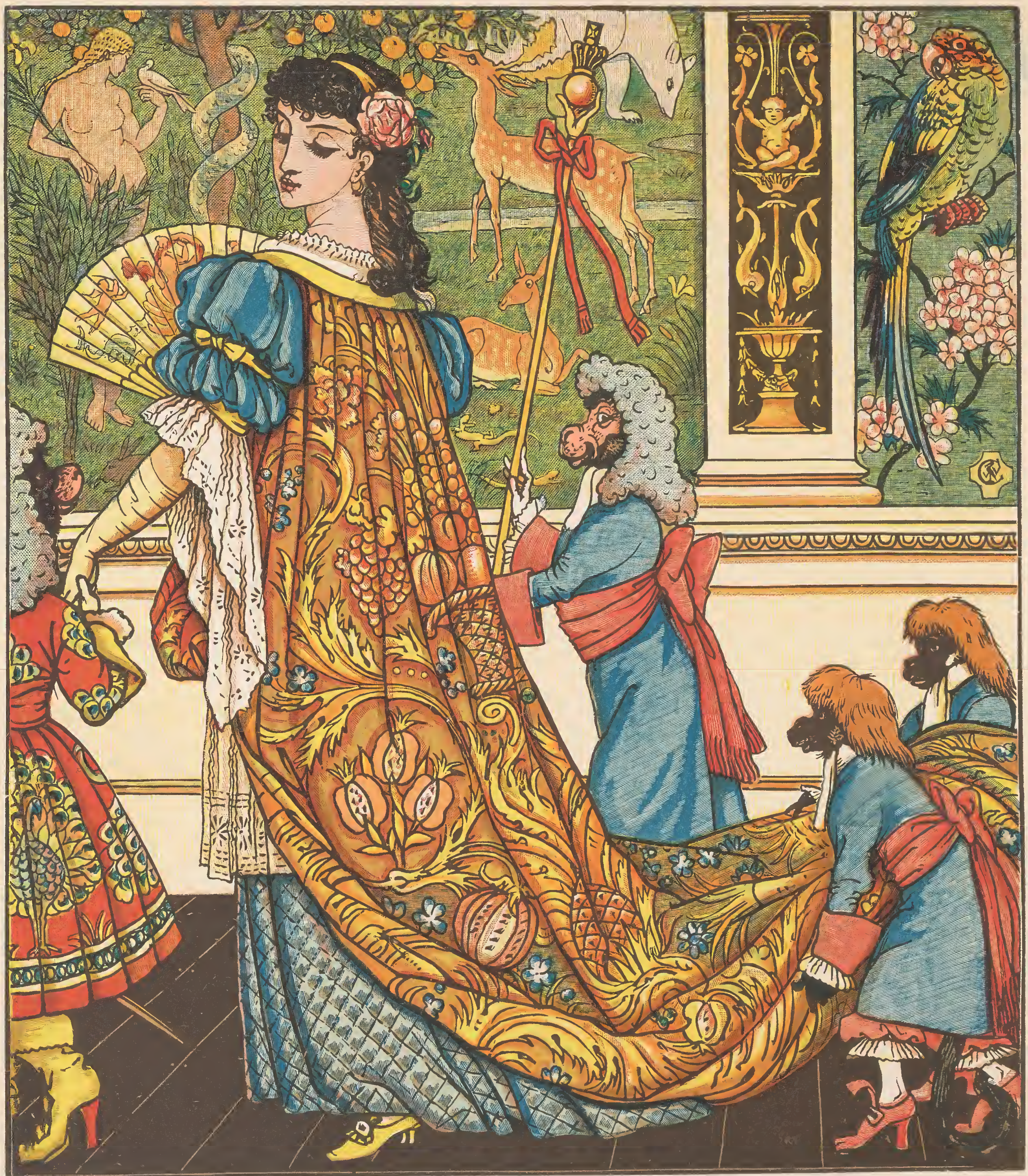


she would like some of them to follow her and keep her company. Instantly two tall young apes, in court dresses, advanced, and placed themselves with great gravity beside her, and two sprightly little monkeys took up her train as pages. From this time the monkeys always waited upon her with all the attention and respect that officers of a royal household are accustomed to pay to queens.

Beauty was now, in fact, quite the Queen of the palace, and all her wishes were gratified; but, excepting at supper-time, she was always alone; the Beast then appeared, and behaved so agreeably that she liked him more and more. But to his question, "Beauty, will you marry me?" he never could get any other answer than a shake of the head from her, on which he always took his leave very sadly.

Although Beauty had everything she could wish for she was not happy, as she could not forget her father, and brothers, and sisters. At last, one evening, she begged so hard of the Beast to let her go home that he agreed to her wish, on her promising not to stay away longer than two months, and gave her a ring, telling her to place it on her dressing-table wheneve1 she desired to go or to return; and then showed her where to find suitable clothes, as well as presents to take home. The poor Beast was more 


\section{Beauty and the Beast.}

sad than ever. She tried to cheer him, saying, "Beauty will soon return," but nothing seemed to comfort him. Beauty then went to her room, and before retiring to rest she took care to place the ring on the dressing-table. When she awoke next morning, what was her joy at finding herself in her father's house, with the gifts and clothes from the palace at her bed-side.

At first she wondered where she was; but she soon heard the voice of her father, and, rushing out, she flung her arms round his neck. The father and daughter had much to say to each other. Beauty related all that had happened to her at the palace. Her father, enriched by the liberality of the Beast, had left his old house, and now lived in a very large city, and her sisters were engaged to be married to young men of good family.

When she had passed some weeks with her family, Beauty found that her sisters, who were secretly vexed at her good fortune, still looked upon her as a rival, and treated her with coldness. Besides this, she remembered her promise to the Beast, and resolved to return to him. But her father and brothers begged her to stay a day or two longer, and she could not resist their entreaties. But one night she dreamed that the poor Beast was lying dead in the palace garden; she awoke in a fright, 



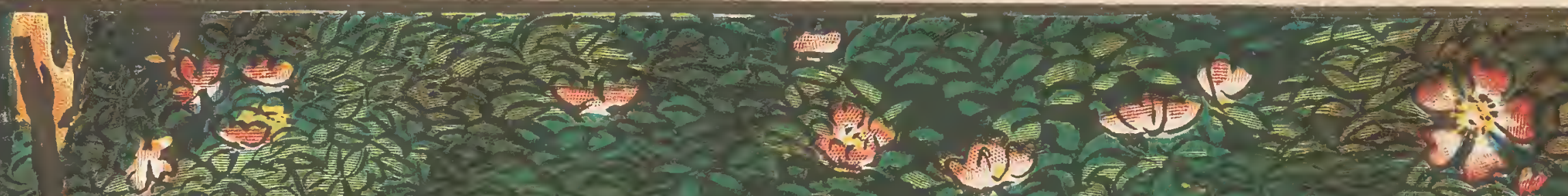

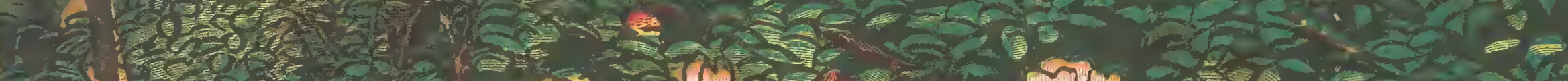

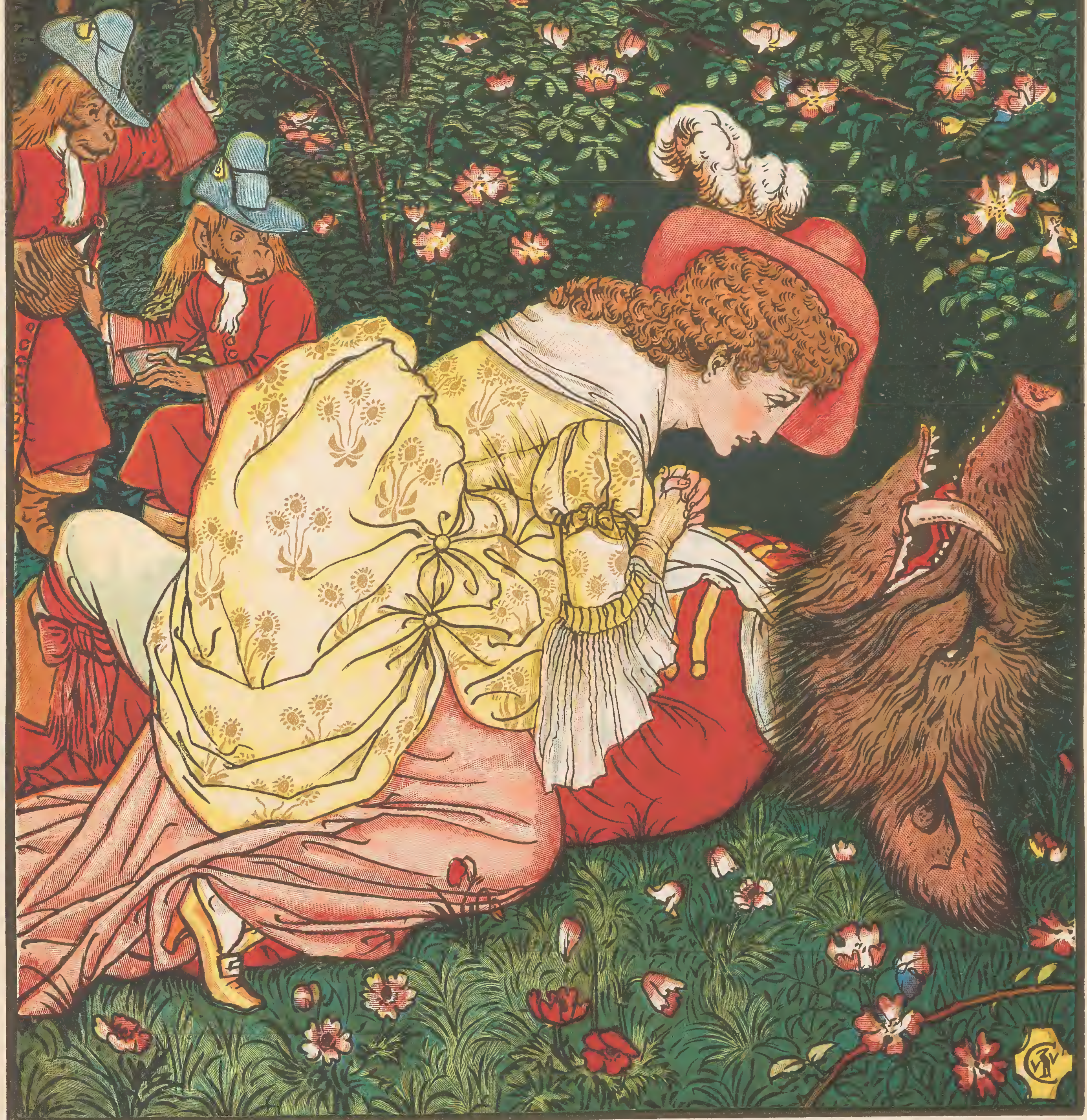


looked for her ring, and placed it on the table. In the morning she was at the Palace again, but the Beast was nowhere to be found: at last she ran to the place in the garden that she had dreamed about, and there, sure enough, the poor Beast was, lying senseless on his back.

At this sight Beauty wept and reproached herself for having caused his death. She ran to a fountain and sprinkled his face with water. The Beast opened his eyes, and as soon as he could speak, he said, sorrowfully, "Now that I see you once more, I die contented." "No, no!" she cried, "you shall not die! Oh, live to be my husband, and Beauty will be your faithful wife!" The moment she had uttered these words, a dazzling light shone everywhere; the Palace windows glittered with lamps, and music was heard around. To her great wonder, a handsome young Prince stood before her, who said that her words had broken the spell of a magician, by which he had been doomed to wear the form of a Beast, until a beautiful girl should love him in spite of his ugliness. The grateful Prince now claimed Beauty as his wife. The Merchant was soon informed of his daughter's good fortune, and the Prince was married to Beauty on the following day. 

, 


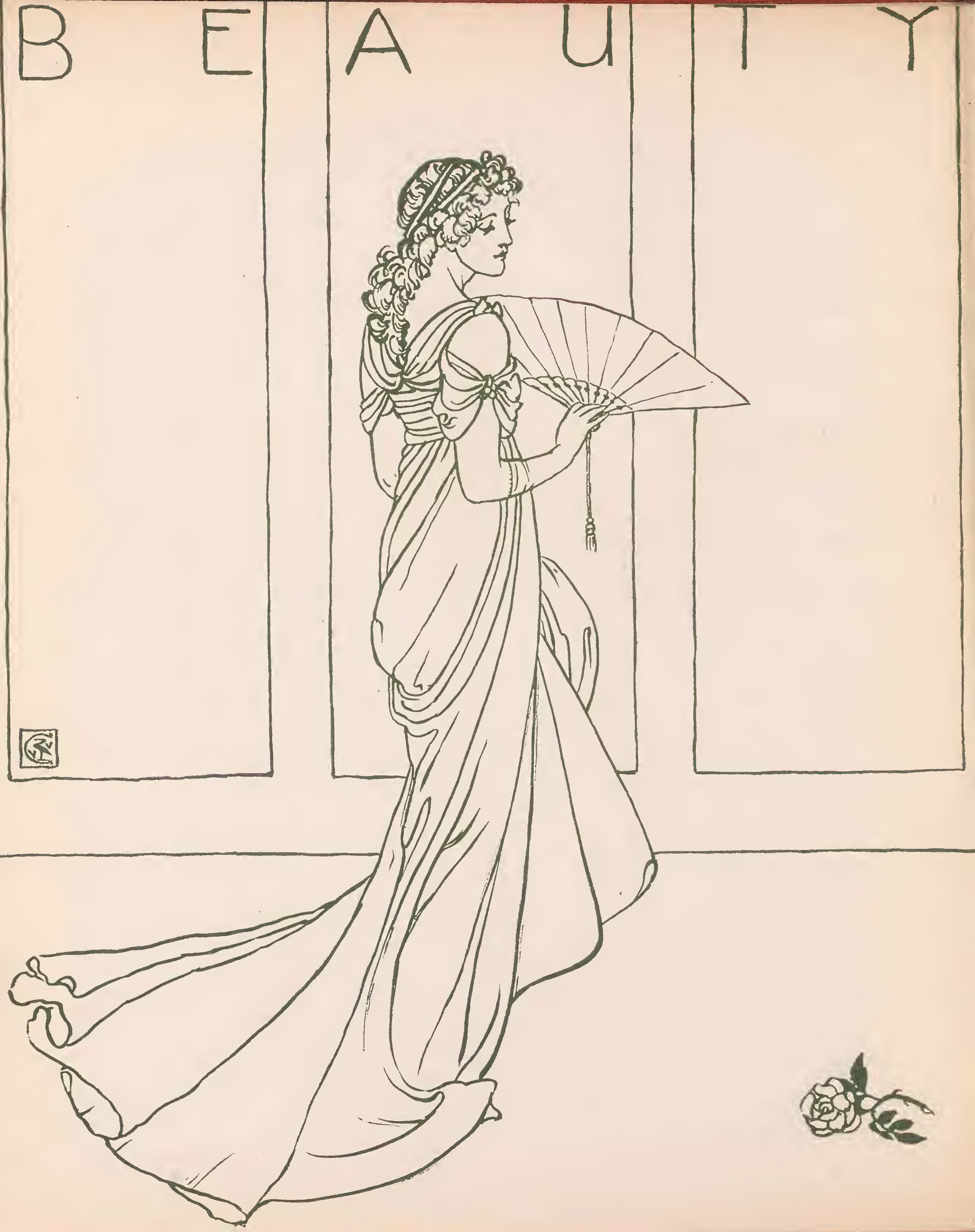


- WALTERCRANÉS.

- plcturebooks.

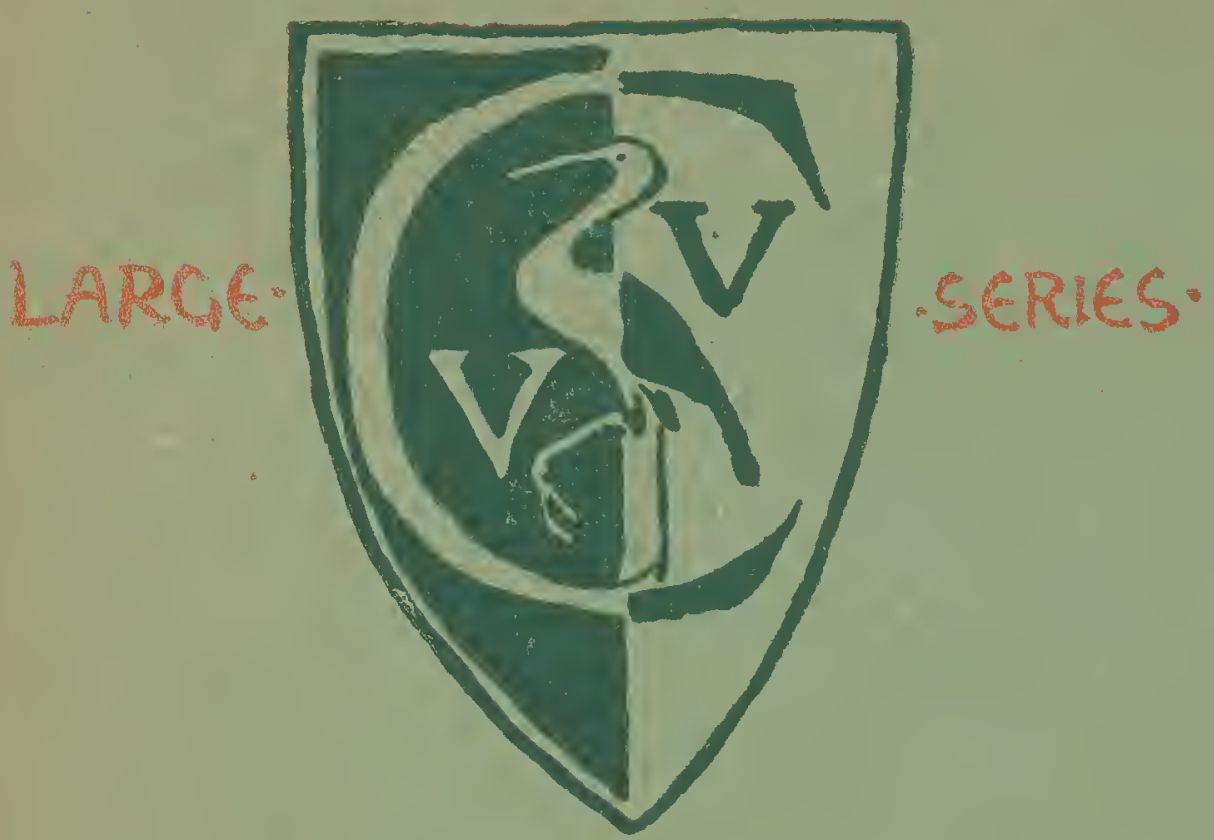

ENCRAVED \& PRINTED

BY

BDMUND EVANS 


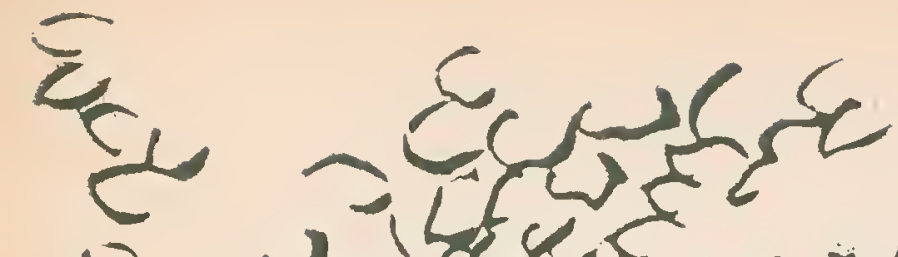

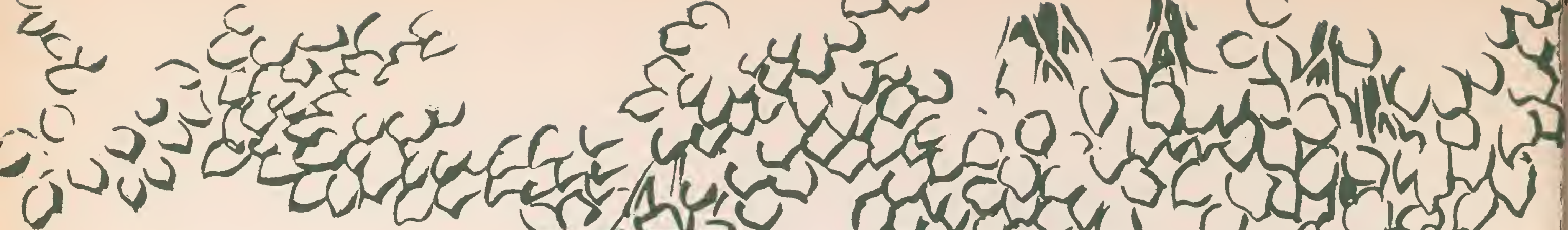

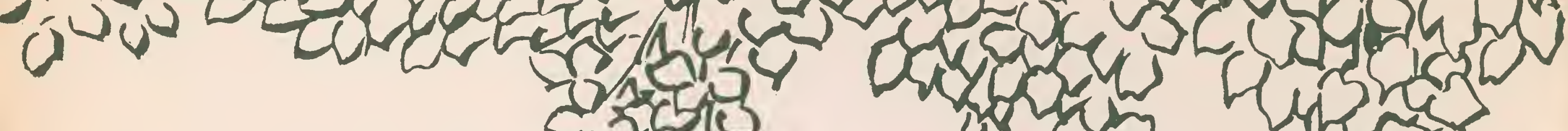

THE FROG

PRINCE

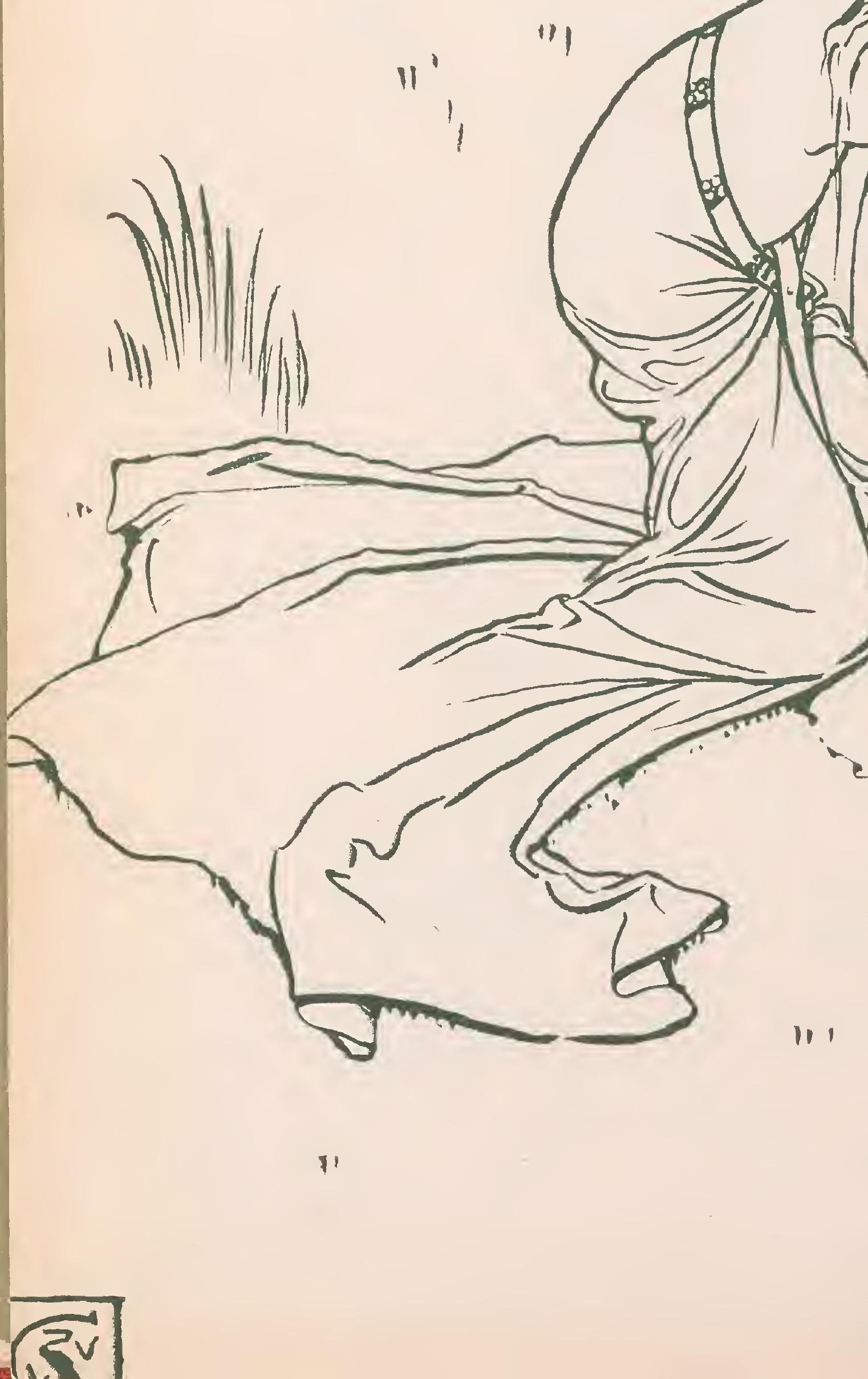

cिive
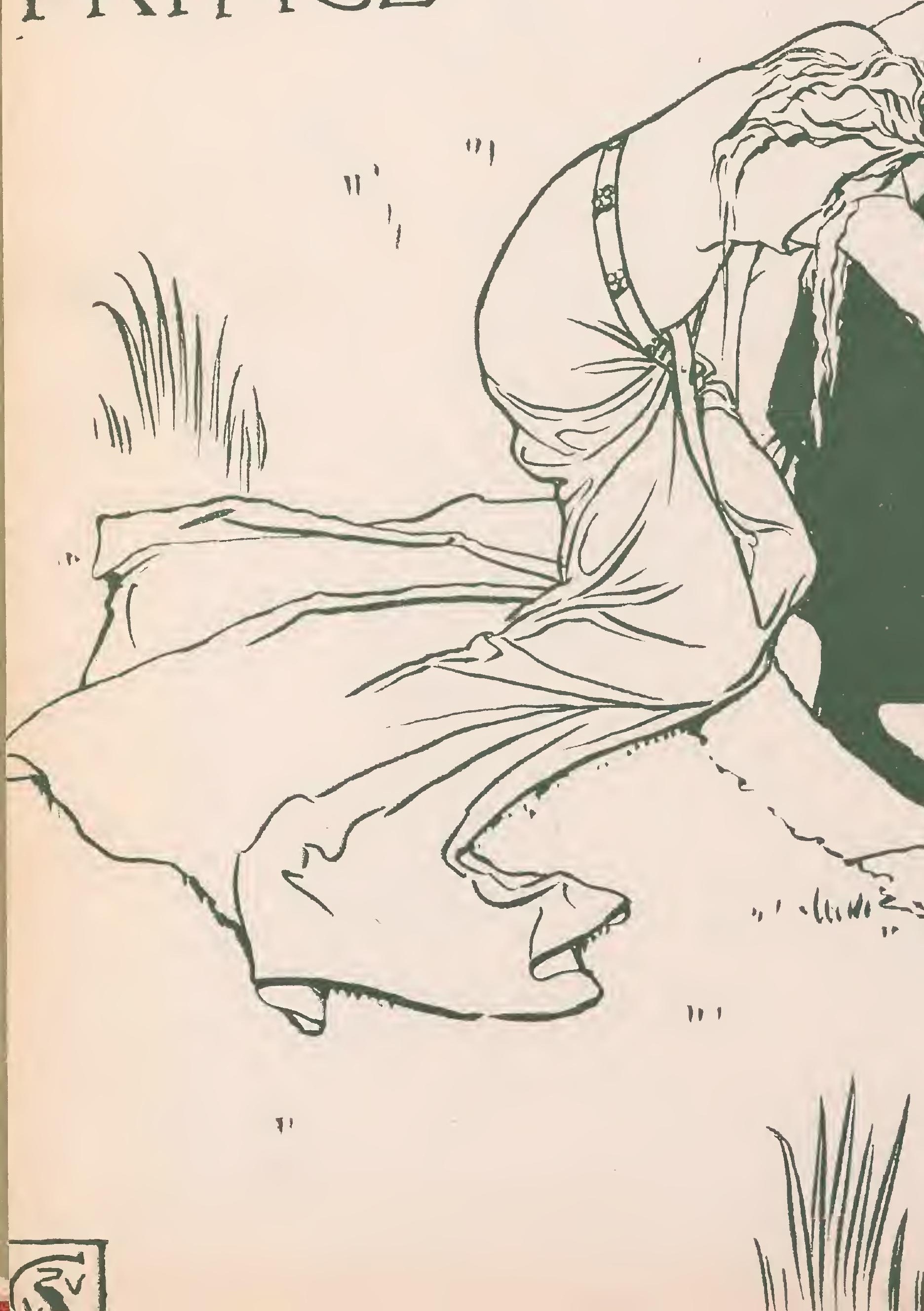

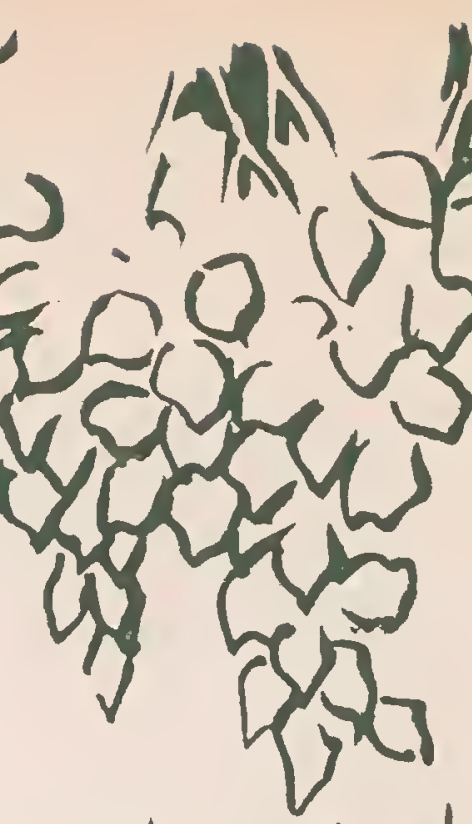

시
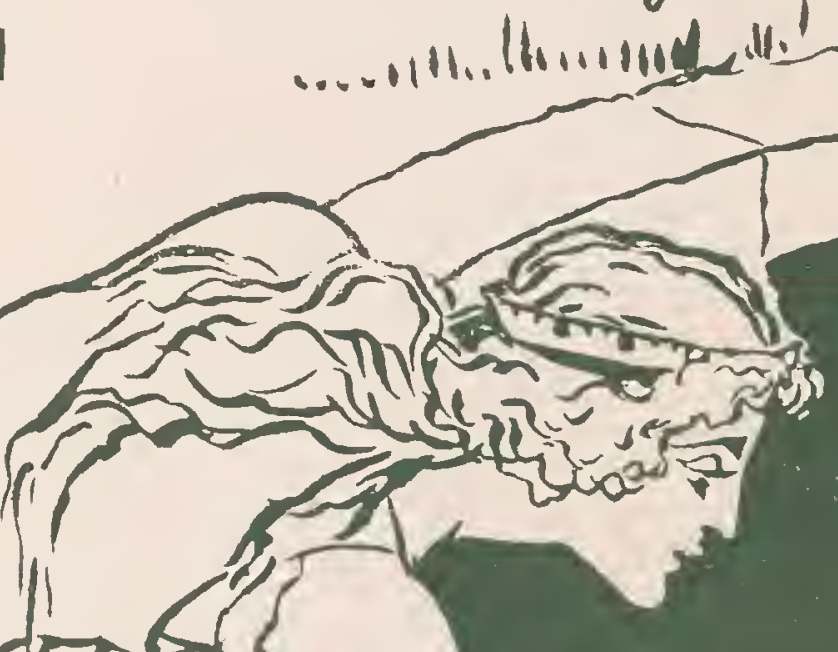

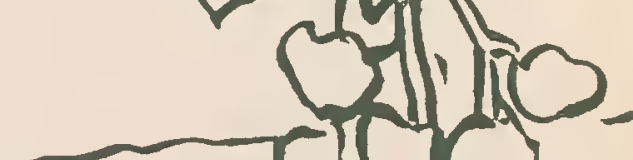

.
(1)

25

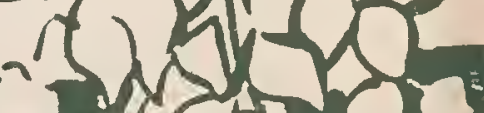

(n) (4)

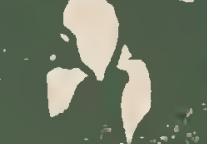


$($ (n)

< SIR

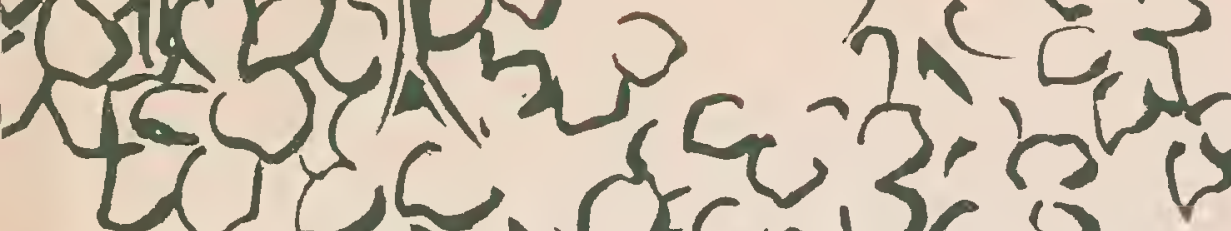

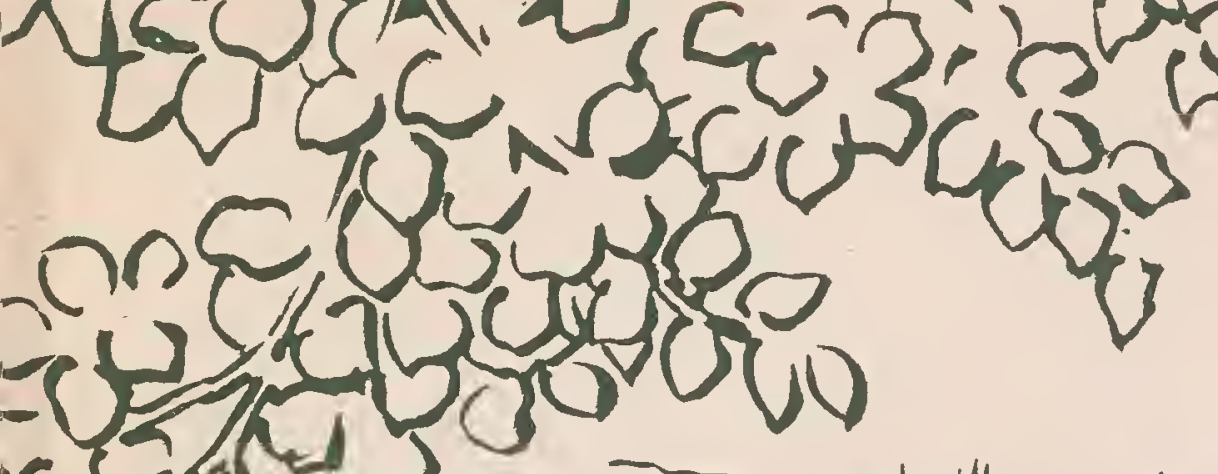

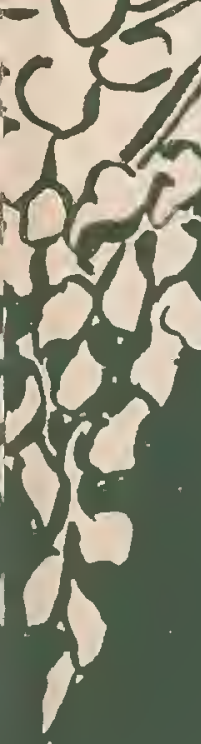

4

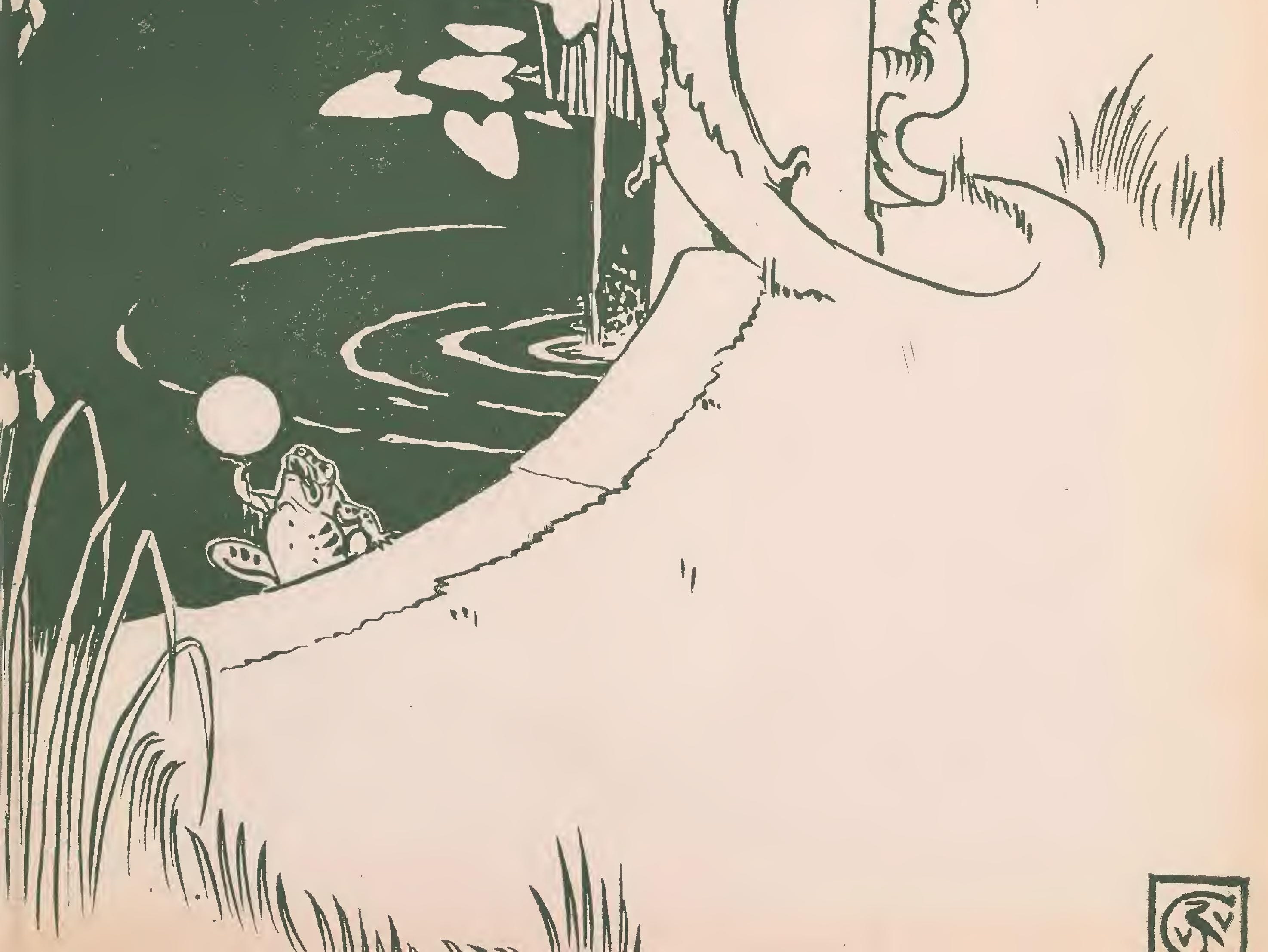




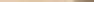




\section{THE FROG PRINCE}

$\mathrm{N}$ the olden time, when wishing was having, there lived a 1 King, whose daughters were all beautiful; but the youngest was so exceedingly beautiful that the Sun himself, although he saw her very often, was enchanted every time she came out into the sunshine.

Near the castle of this King was a large and gloomy forest, and in the midst stood an old lime-tree, beneath whose branches splashed a little fountain; so, whenever it was very hot, the King's youngest daughter ran off into this wood, and sat down by the side of this fountain; and, when she felt dull, would often divert herself by throwing a golden ball up in the air and catching it. And this was her favourite amusement.

Now, one day it happened, that this golden ball, when the King's daughter threw it into the air, did not fall down into her hand, but on the grass; and then it rolled past her into the fountain. The King's daughter followed the ball with her eyes, but it disappeared beneath the water, which was so deep that no one could see to the bottom. Then she began to lament, and to cry 


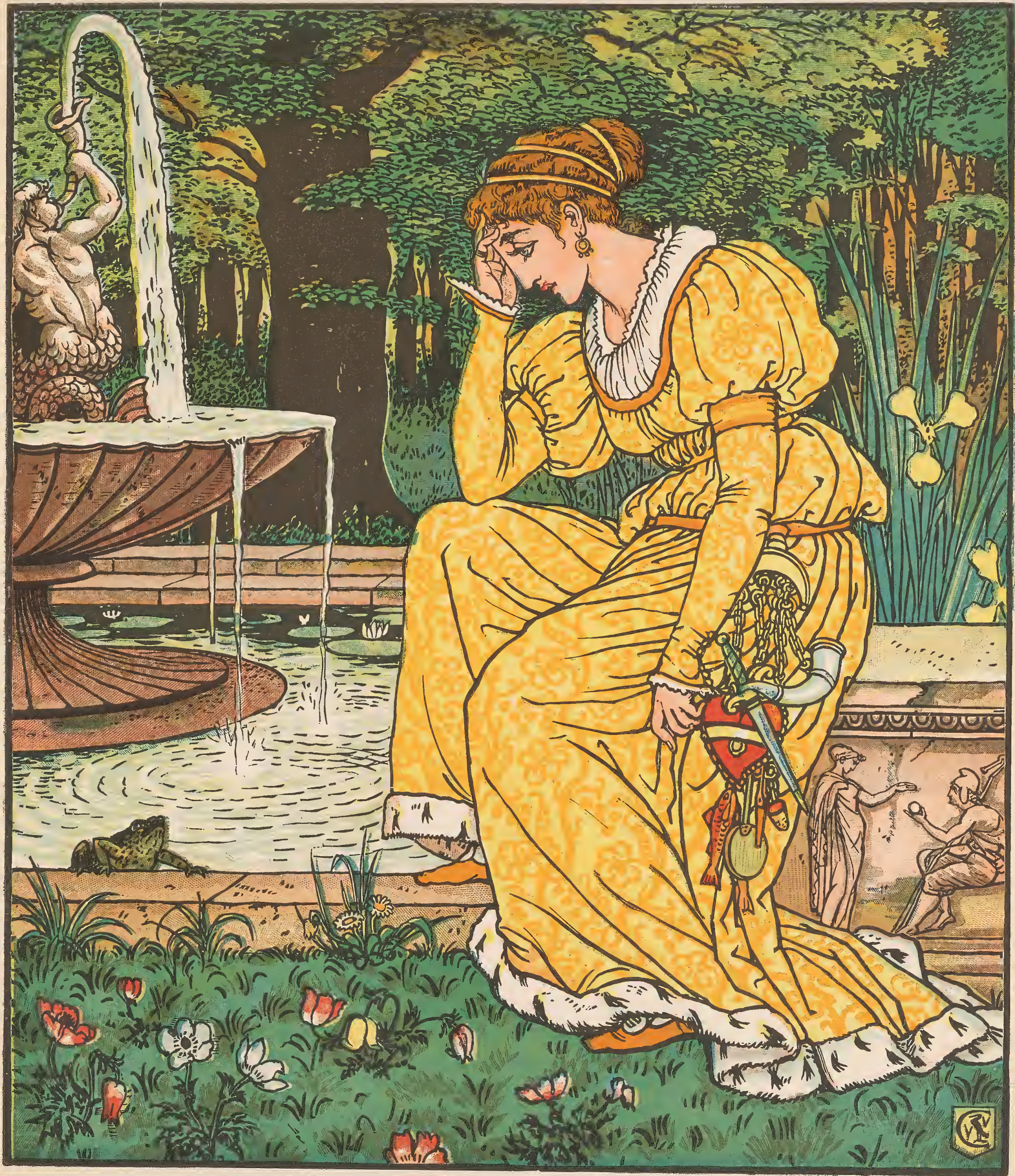





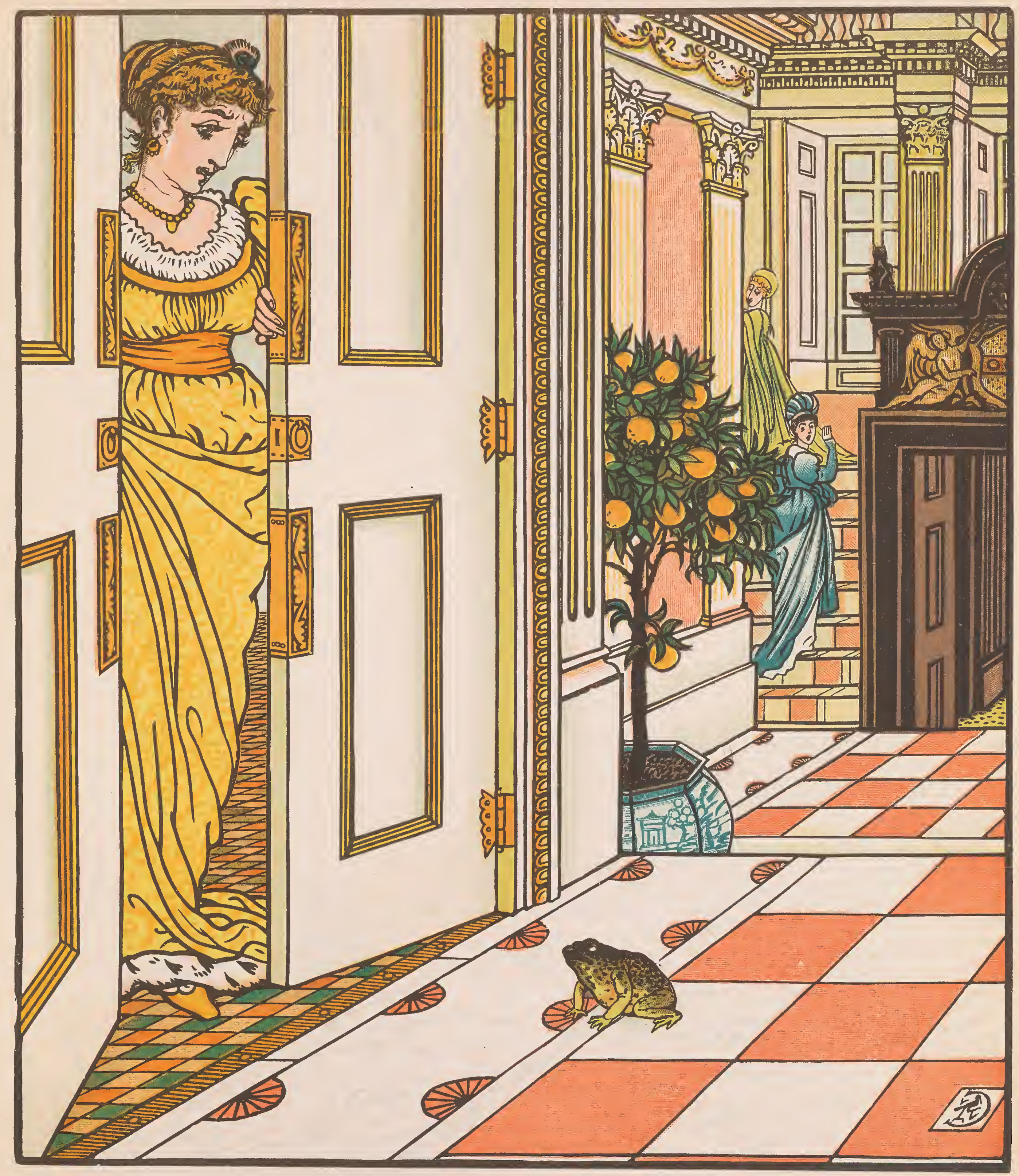



louder and louder; and, as she cried, a voice called out, "Why weepest thou, O King's daughter? thy tears would melt even a stone to pity." And she looked around to the spot whence the voice came, and saw a Frog stretching his thick ugly head out of the water. "Ah! you old water-paddler," said she, "was it you that spoke? I am weeping for my golden ball, which has slipped away from me into the water."

"Be quiet, and do not cry," answered the Frog; "I can give thee good advice. But what wilt thou give me if I fetch thy plaything up again?"

"What will you have, dear Frog?" said she. "My dresses, my pearls and jewels, or the golden crown which I wear?"

The Frog answered, "Dresses, or jewels, or golden crowns, are not for me; but if thou wilt love me, and let me be thy companion and playfellow, and sit at thy table, and eat from thy little golden plate, and drink out of thy cup, and sleep in thy little bed, -if thou wilt promise me all these, then will I dive down and fetch up thy golden ball."

"Oh, I will promise you all," said she, "if you will only get me my ball." But she thought to herself, "What is the silly Frog chattering about? Let him remain in the water with his equals; he cannot mix in society." But the Frog, as soon as he had received her promise, drew his head under the water and dived down. Presently he swam up again with the ball in his mouth, and threw it on the grass. The King's daughter was full of joy 
when she again saw her beautiful plaything; and, taking it up; she ran off immediately. "Stop! stop!" cried the Frog; "take me with thee. I cannot run as thou canst." But all his croaking was useless; although it was loud enough, the King's daughter did not hear it, but, hastening home, soon forgot the poor Frog, who was obliged to leap back into the fountain.

The next day, when the King's daughter was sitting at table with her father and all his courtiers, and was eating from her own little golden plate, something was heard coming up the marble stairs, splish-splash, splish-splash; and when it arrived at the top, it knocked at the door, and a voice said, "Open the door, thou youngest daughter of the King!" So she rose and went to see who it was that called her; but when she opened the door and caught sight of the Frog, she shut it again with great vehemence, and sat down at the table, looking very pale. But the King perceived that her heart was beating violently, and asked her whether it were a giant who had come to fetch her away who stood at the door. "Oh, no!" answered she; " it is no giant, but an ugly Frog."

"What does the Frog want with you?". said the King.

"Oh, dear father, when I was sitting yesterday playing by the fountain, my golden ball fell into the water, and this Frog fetched it up again because I cried so much: but first, I must tell you, he pressed me so much, that I promised him he should be my companion. I never thought that he could come out of the water, but somehow he has jumped out, and now he wants to come in here." 


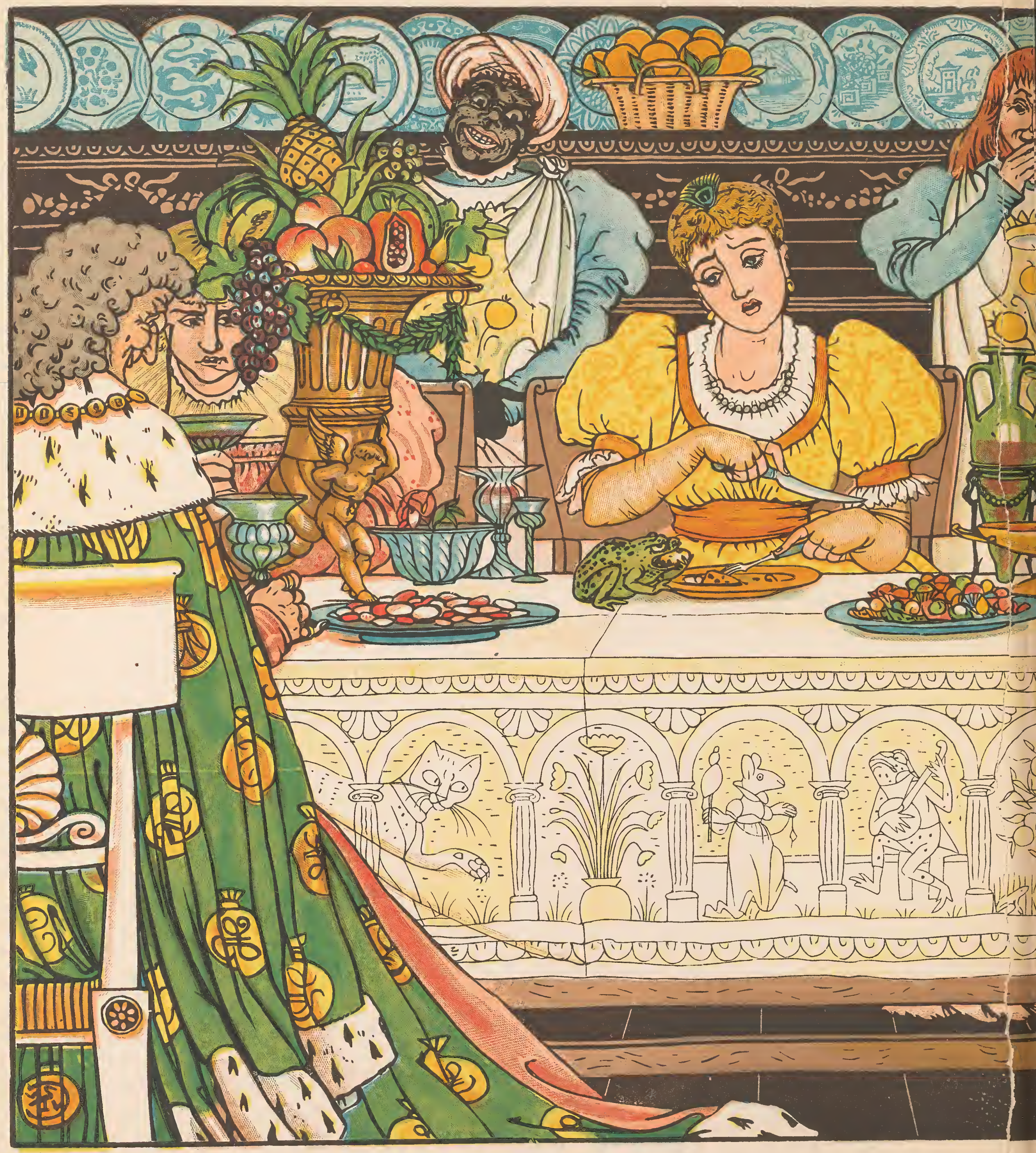




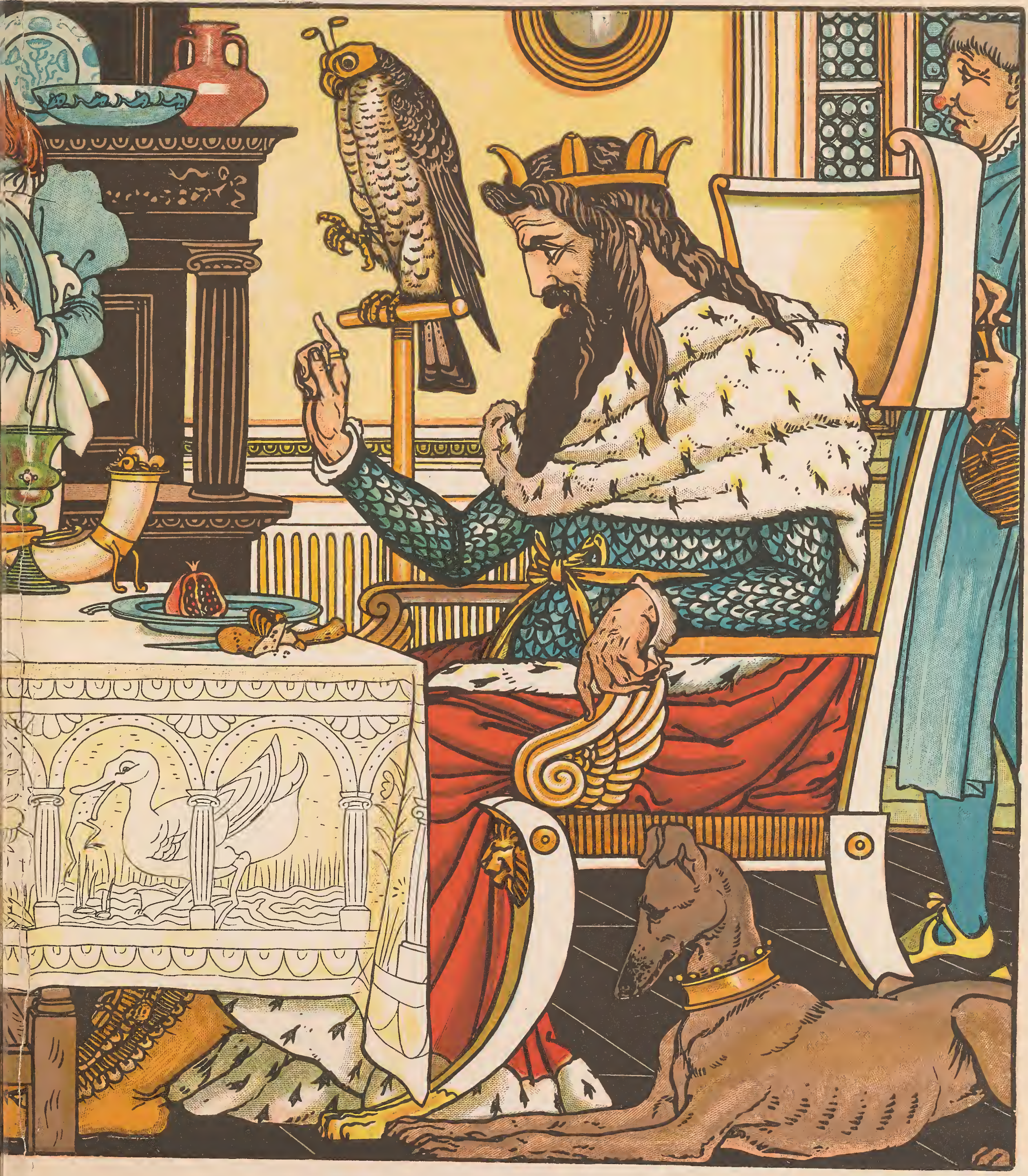





\section{The Frog Prince.}

At that moment there was another knock, and a voice said,--

"King's daughter, youngest,

Open the door.

Hast thou forgotten

Thy promises made

At the fountain so clear

'Neath the lime-tree's shade?

'King's daughter, youngest,

Open the door."

Then the King said, "What you have promised, that you must perform; go and let him in." So the King's daughter went and opened the door, and the Frog hopped in after her right up to her chair: and as soon as she was seated, the Frog said, "Take me up;" but she hesitated so long that at last the King ordered her to obey. And as soon as the Frog sat on the chair, he jumped on to the table, and said, "Now push thy plate near me, that we may eat together." And she did so, but as everyone saw, very unwillingly. The Frog seemed to relish his dinner much, but every bit that the King's daughter ate nearly choked her, till at last the Frog said. "I have satisfied my hunger and feel very tired; wilt thou carry me upstairs now into thy chamber, and make thy bed ready that we may sleep together?" At this speech the King's daughter began to cry, for she was afraid of the cold Frog, and dared not touch him; and besides, he actually wanted to sleep in her own beautiful, clean bed.

But her tears only made the King very angry, and he said, 


\section{The Frog Prince.}

"He who helped you in the time of your trouble, must not now be despised!" So she took the Frog up with two fingers, and put him in a corner of her chamber. But as she lay in her bed, he crept up to it, and said, "I am so very tired that I shall sleep well ; do take me up or I will tell thy father." This speech put the King's daughter in a terrible passion, and catching the Frog up, she threw him with all ner strength against the wall, saying, "Now, will you be quiet, you ugly Frog?"

But as he fell he was changed from a frog into a handsome Prince with beautiful eyes, who, after a little while became, with her father's consent, her dear companion and betrothed. Then he told her how he had been transformed by an evil witch, and that no one but herself could have had the power to take him out of the fountain; and that on the morrow they would go together into his own kingdom.

The next morning, as soon as the sun rose, a carriage drawn by eight white horses, with ostrich feathers on their heads, and golden bridles, drove up to the door of the palace, and behind the carriage stood the trusty Henry, the servant of the young Prince. When his master was changed into a frog, trusty Henry had grieved so much that he had bound three iron bands round his heart, for fear it should break with grief and sorrow. But now that the carriage was ready to carry the young Prince to his own country, the faithful Henry helped in the bride and bridegroom, and placed himself in the seat behind, full of joy at his master's 


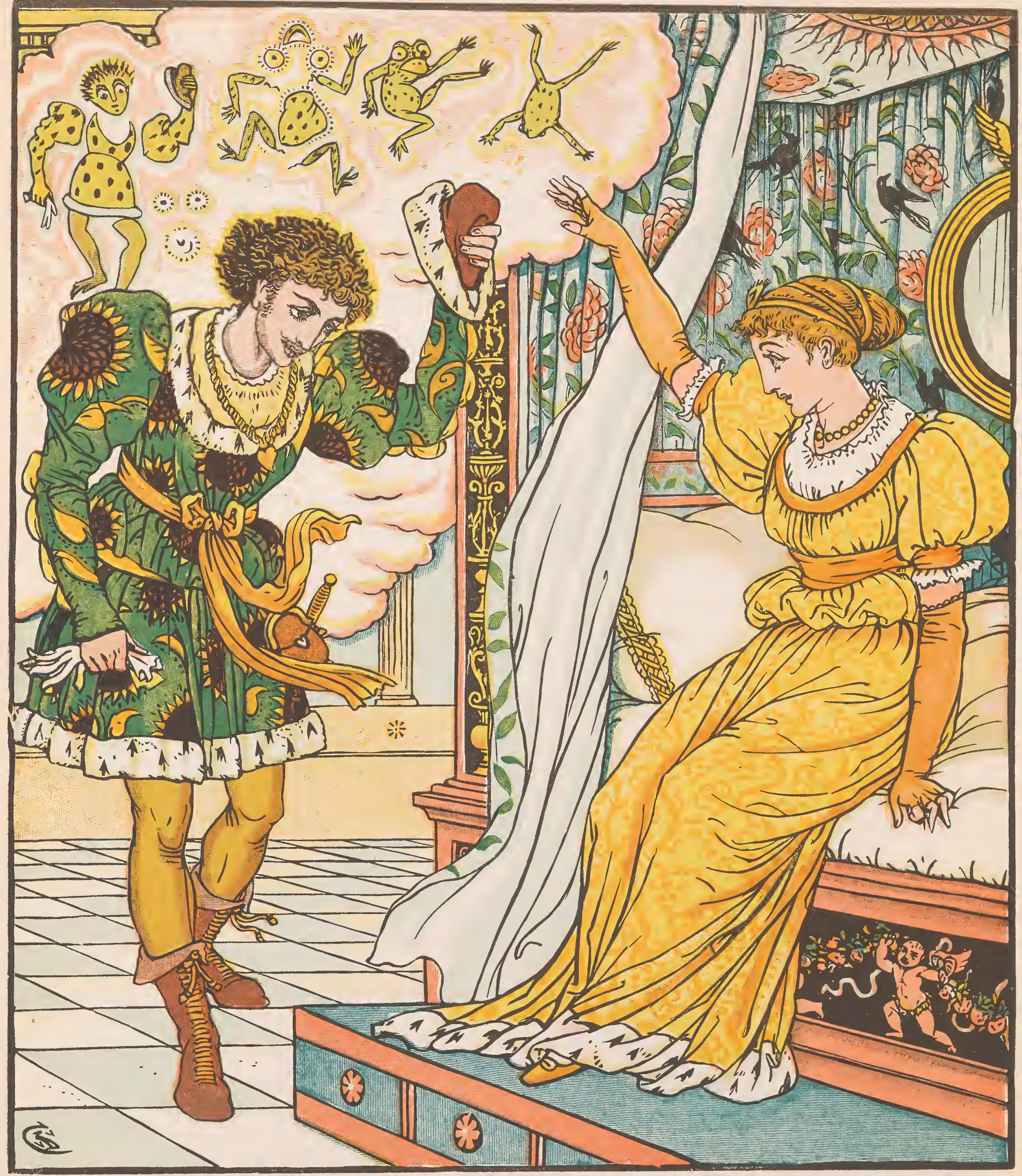




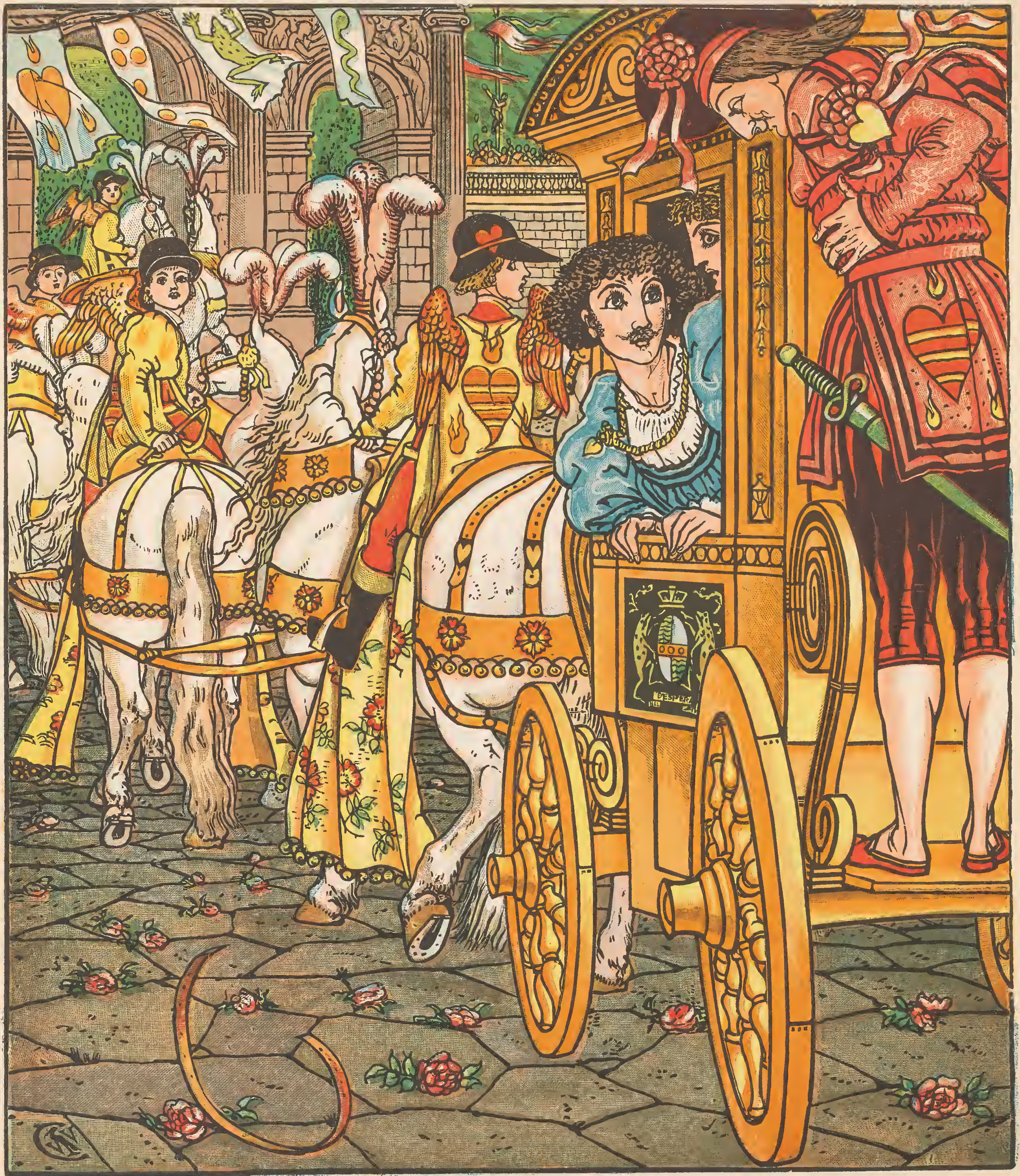




\section{The Frog Prince.}

release. They had not proceeded far when the Prince heard a crack as if something had broken behind the carriage; so he put his head out of the window and asked Henry what was broken, and Henry answered, "It was not the carriage, my master, but a band which I bound round my heart when it was in such grief because you were changed into a frog."

Twice afterwards on the journey there was the same noise, and each time the Prince thought that it was some part of the carriage that had given way; but it was only the breaking of the bands which bound the heart of the trusty Henry, who was thenceforward free and happy. 



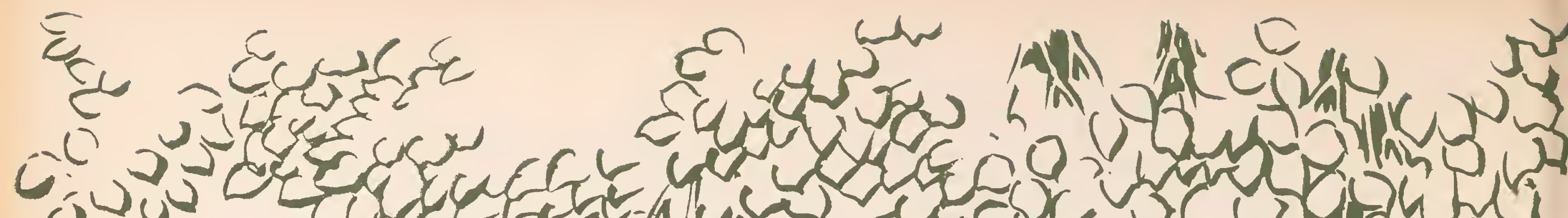

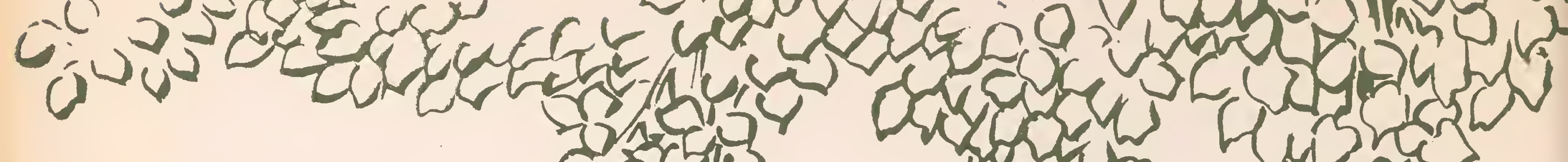

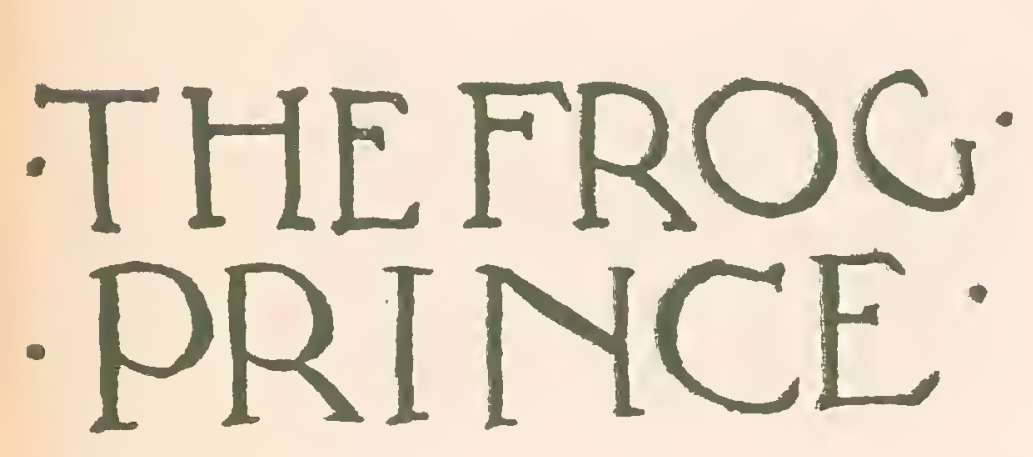
is

1

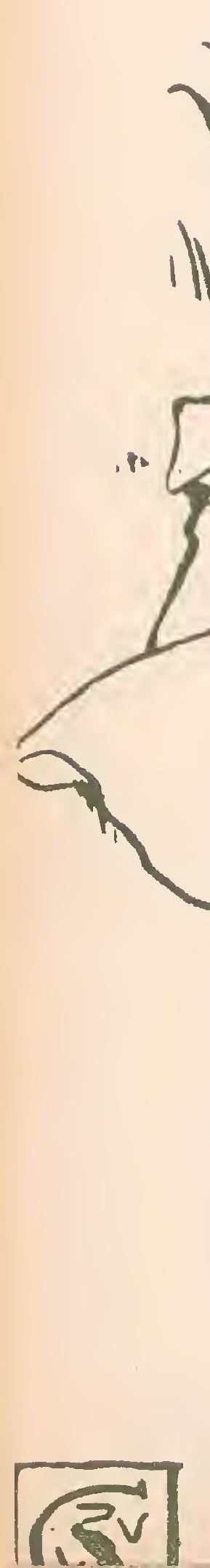

) 111$)(\log (6)$
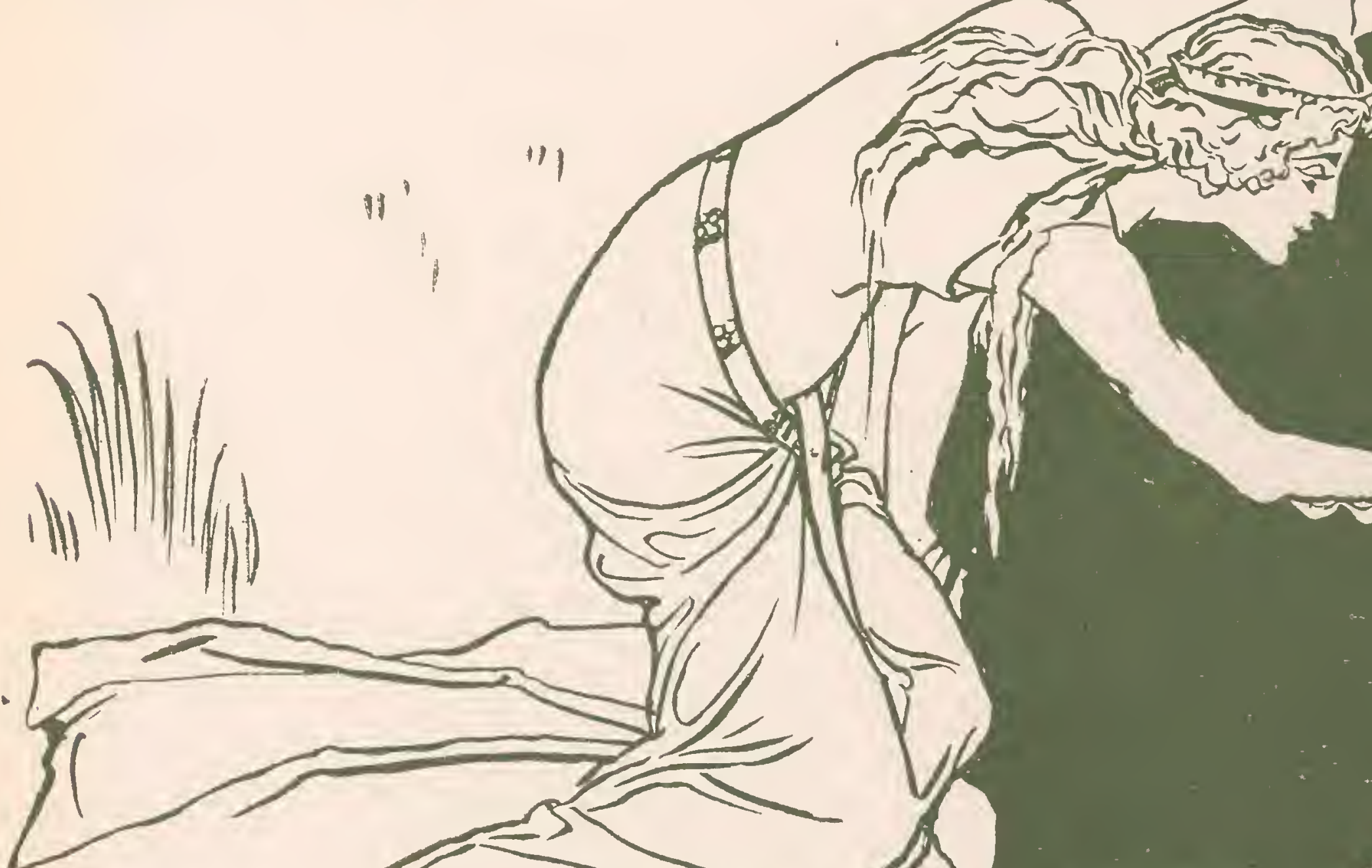

$\sqrt{11} \cdots$

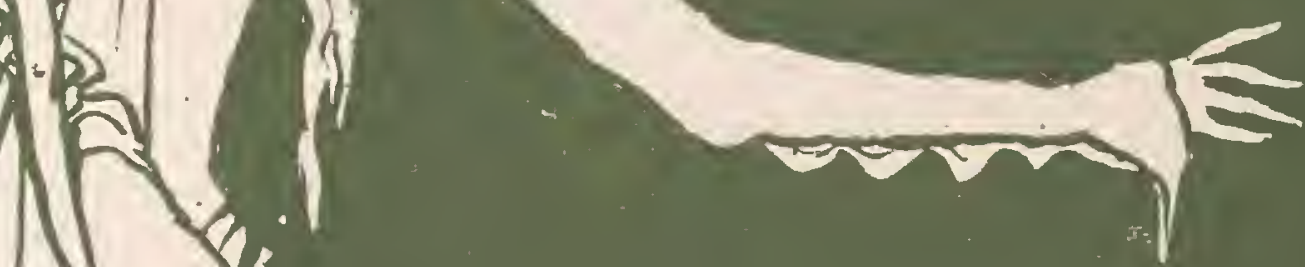

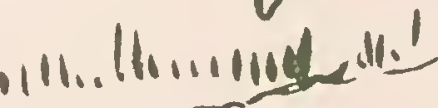

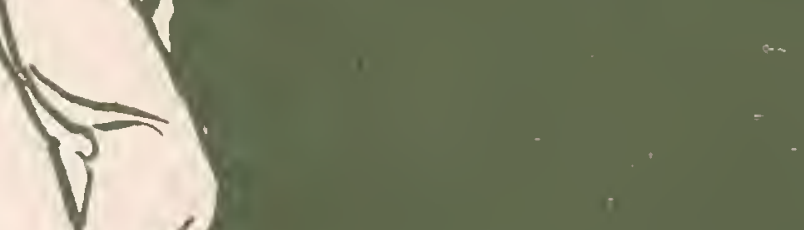


- MALTERERARES.

- PICTUREBOOKS.

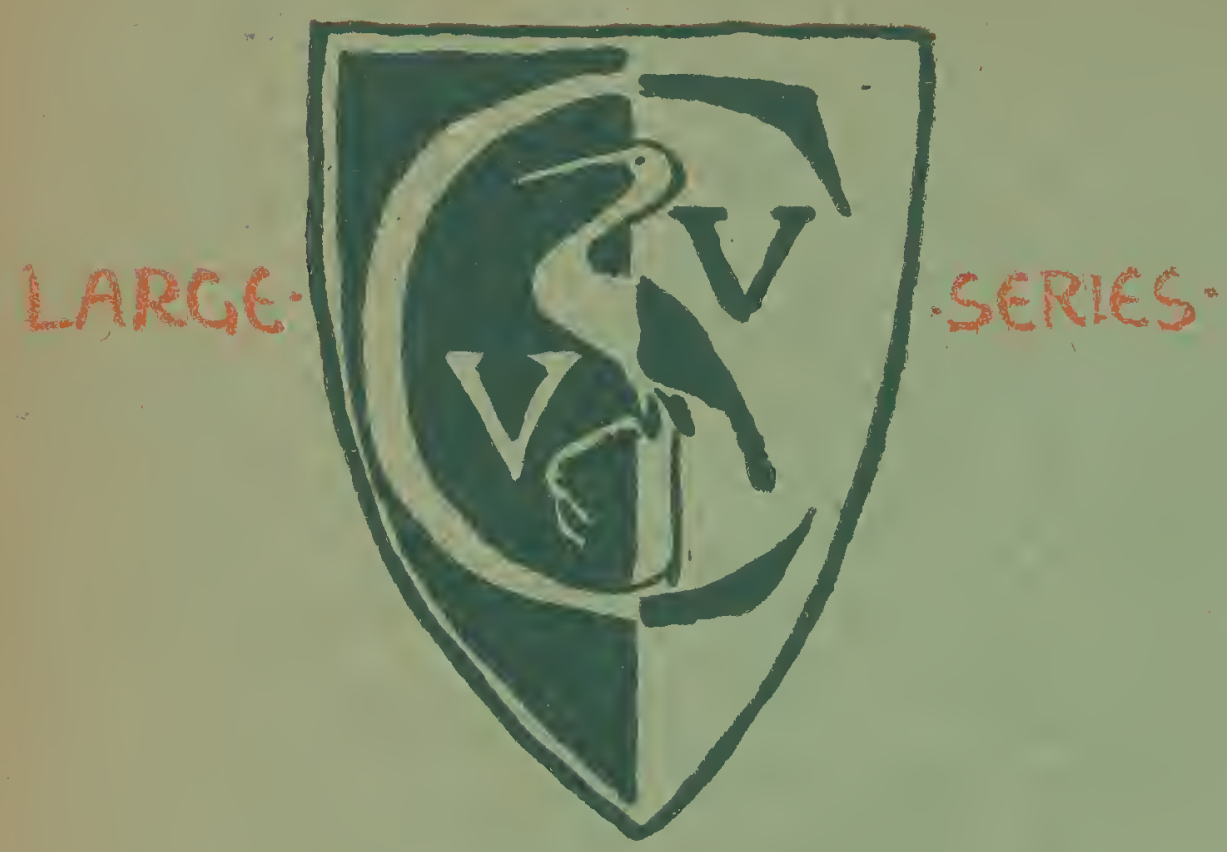

ERGRAVED \& PRINTED

$\mathrm{BY}$

EDMUND EVANS 


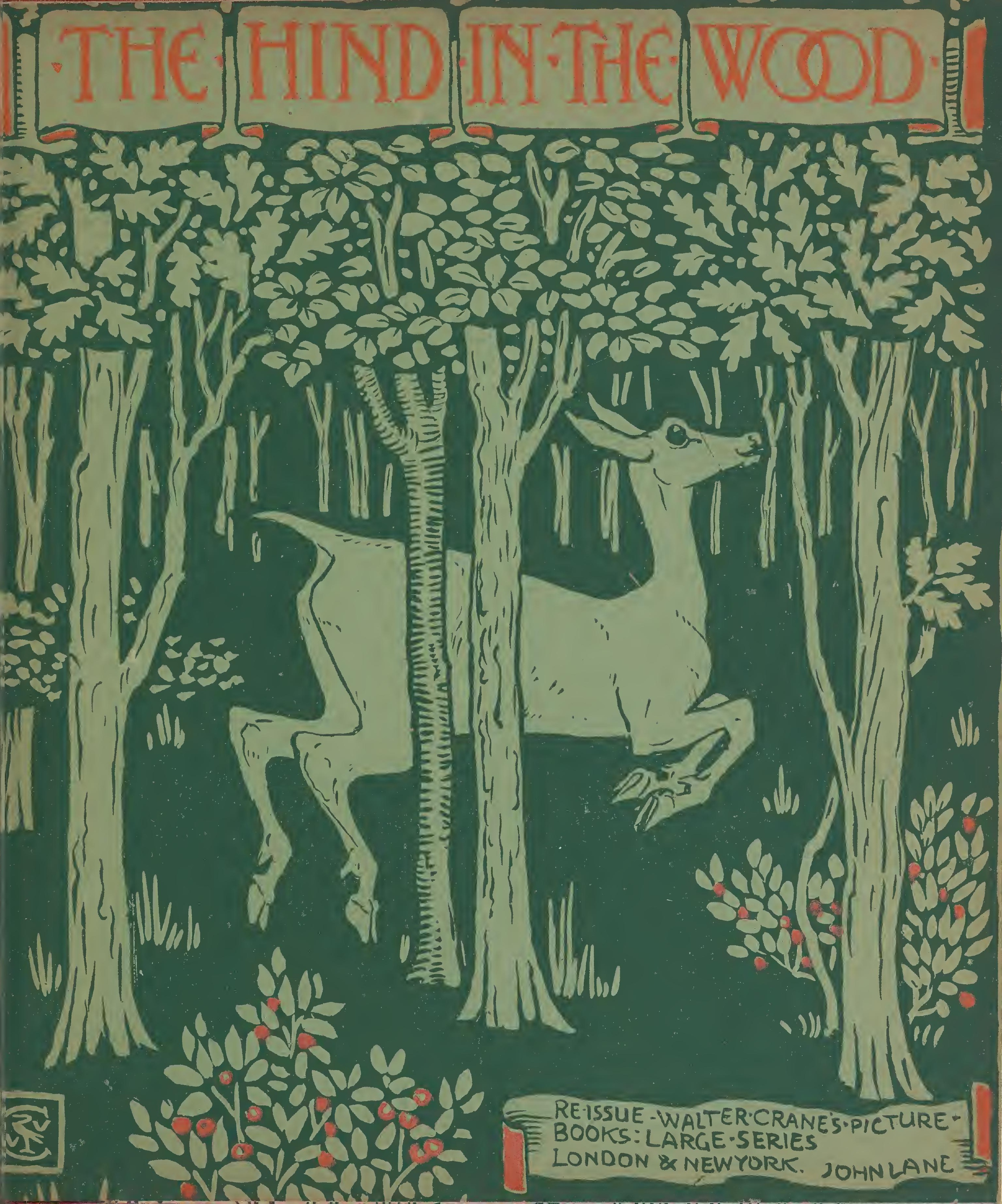




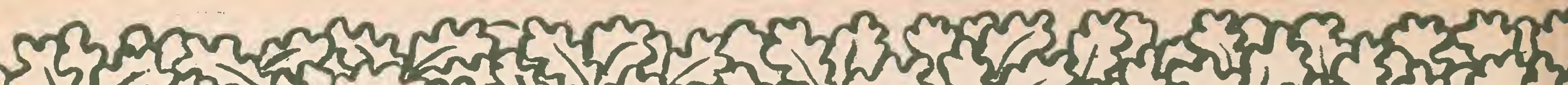
(2) 5150

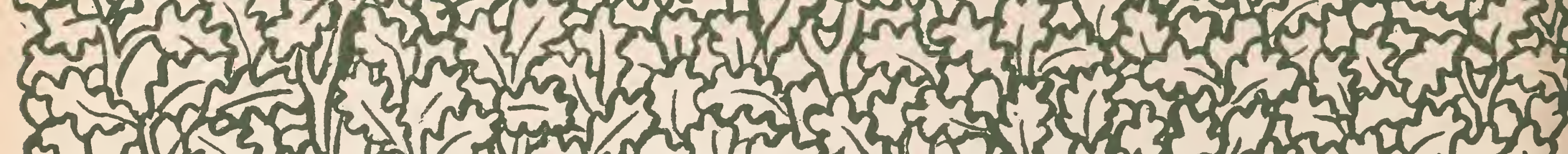

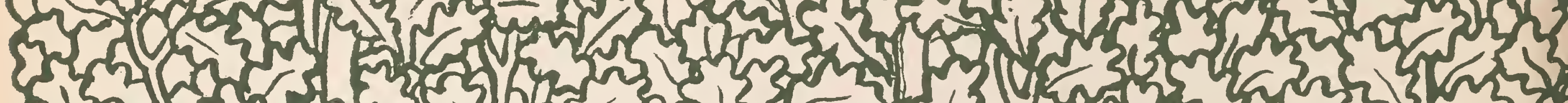
5 s.

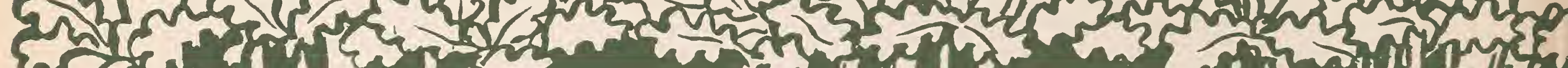

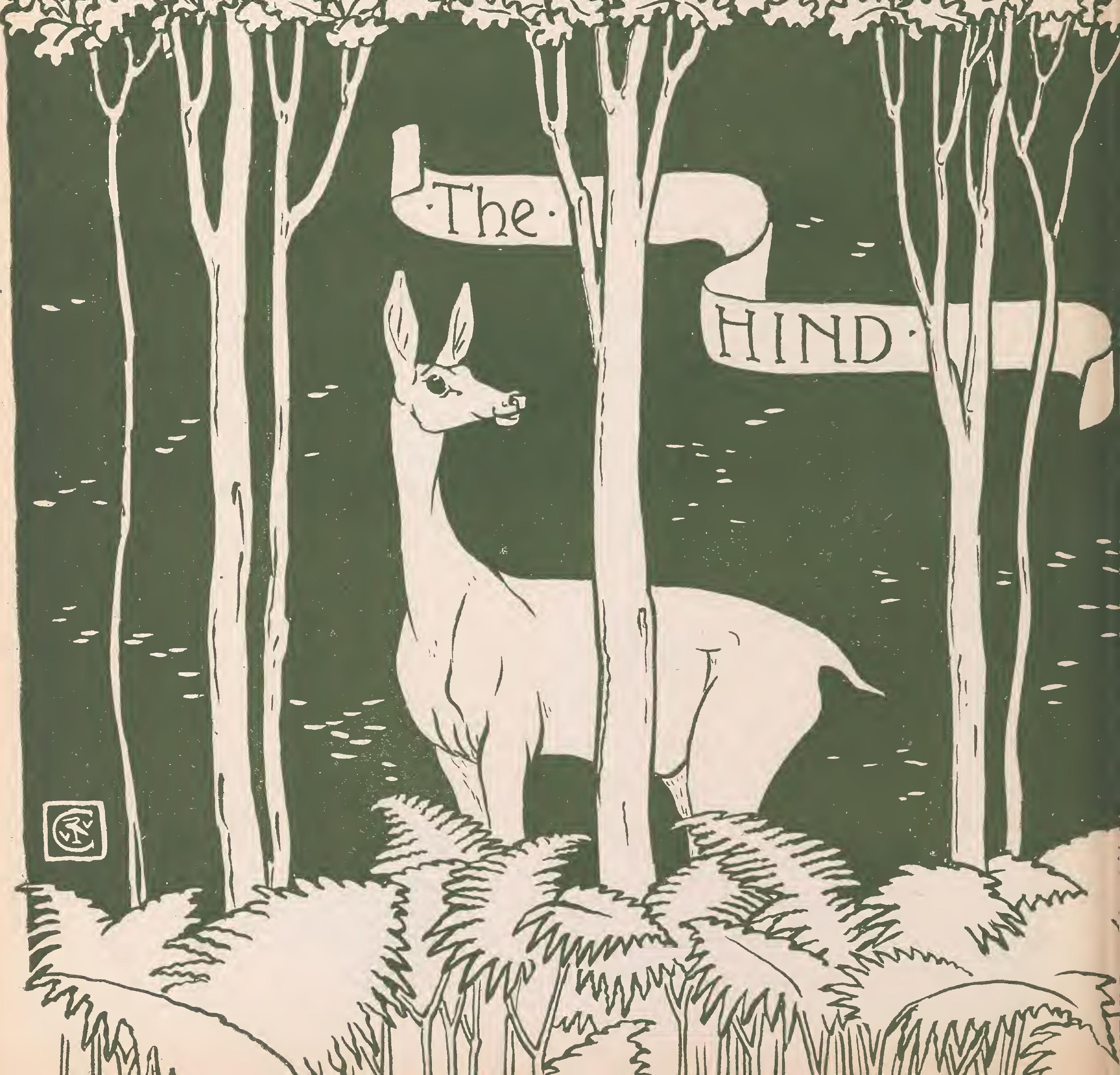




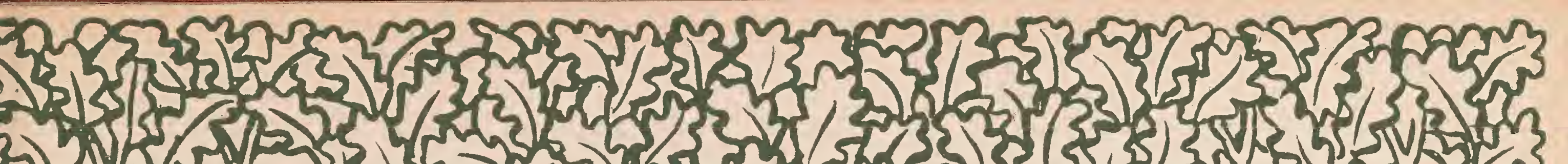

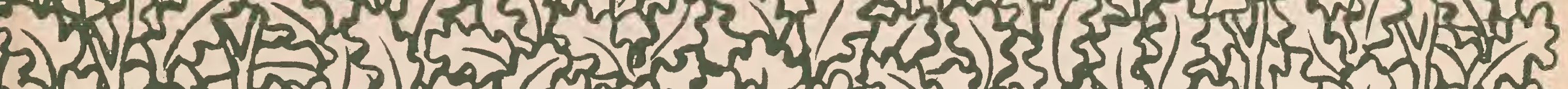

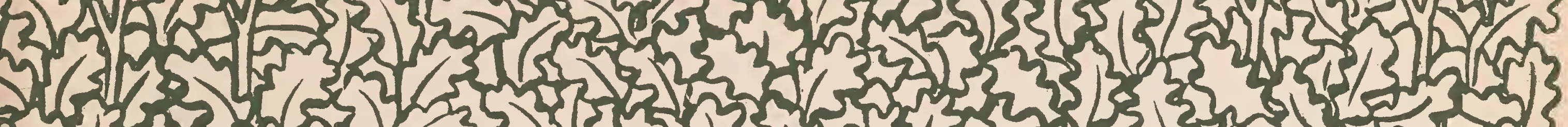

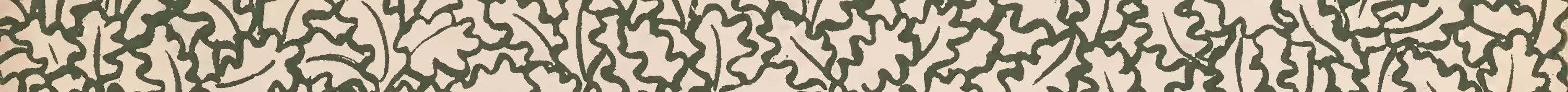

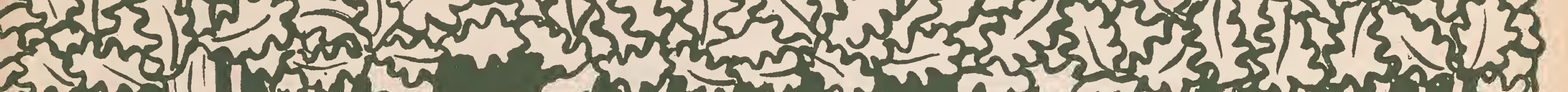

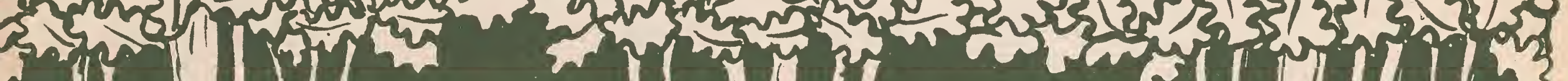

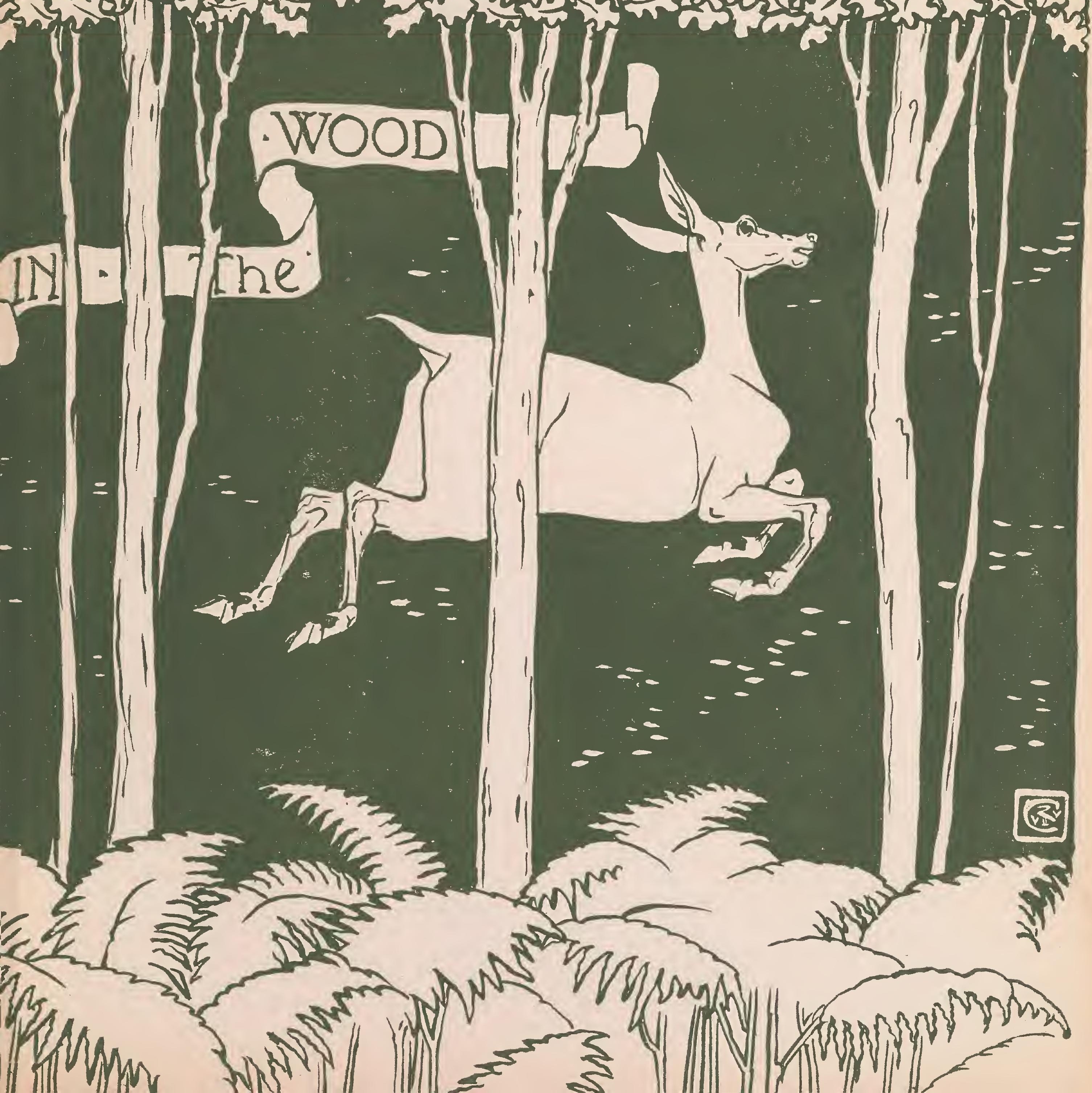






\section{THE HIND IN THE WOOD.}

NCE upon a time there was a King and Queen who were very happy together, but great regret was felt that they had no heir. One day when the Queen was sitting by a fountain, a large crab appeared, and said, "Great Queen, you shall have your wish." The crab then changed into a handsome little old woman, and walked out of the fountain without being wetted. She conducted the Queen through a path in the wood which she had never seen before, although she had been in the wood a thousand times.

The Queen's astonishment was increased by the sight of a palace of diamonds. The gates opened, and six fairies issued forth. They all made a courtesy to the Queen, and each presented her with a flower of precious stones. There was a rose, a tulip, an anemone, a columbine, a carnation, and a pomegranate. "Madam," said they, "we are delighted to announce to you that you will have a beautiful Princess, whom you will call Désirée. Send for us the moment she is born, for we wish to endow her with all good qualities; hold the bouquet, and name each flower, thinking of us, and we shall be instantly in your chamber."

The Queen returned to court, and soon after a Princess was born, whom she named Désirée; she took the bouquet, named the flowers one after another, and all the fairies arrived. They took the little Princess upon their knees and kissed her, one endowing her with virtue, another with wit, a third with beauty, the next with good fortune, the fifth with continual health, and the last with the gift of doing everything well which she undertook.

The Queen thanked them for the favours conferred upon the little Princess, when there entered so large a crab that the door was scarcely wide enough for her to pass through. "Ah! ungrateful Queen,". said the crab, "have you so soon forgotten the Fairy of the Fountain, and the service I rendered you by introducing you to my sisters! You have summoned them all, and I alone am neglected!" The Queen asked her pardon; and the fairies, who feared she would endow the child with misery and misfortune, seconded the Queen's endeavours to appease her. "Very well," said she; "I will not do all the mischief to Désirée I had intended. However, I warn you that if she sees the light of day before she is fifteen, it will perhaps cost her her life." 


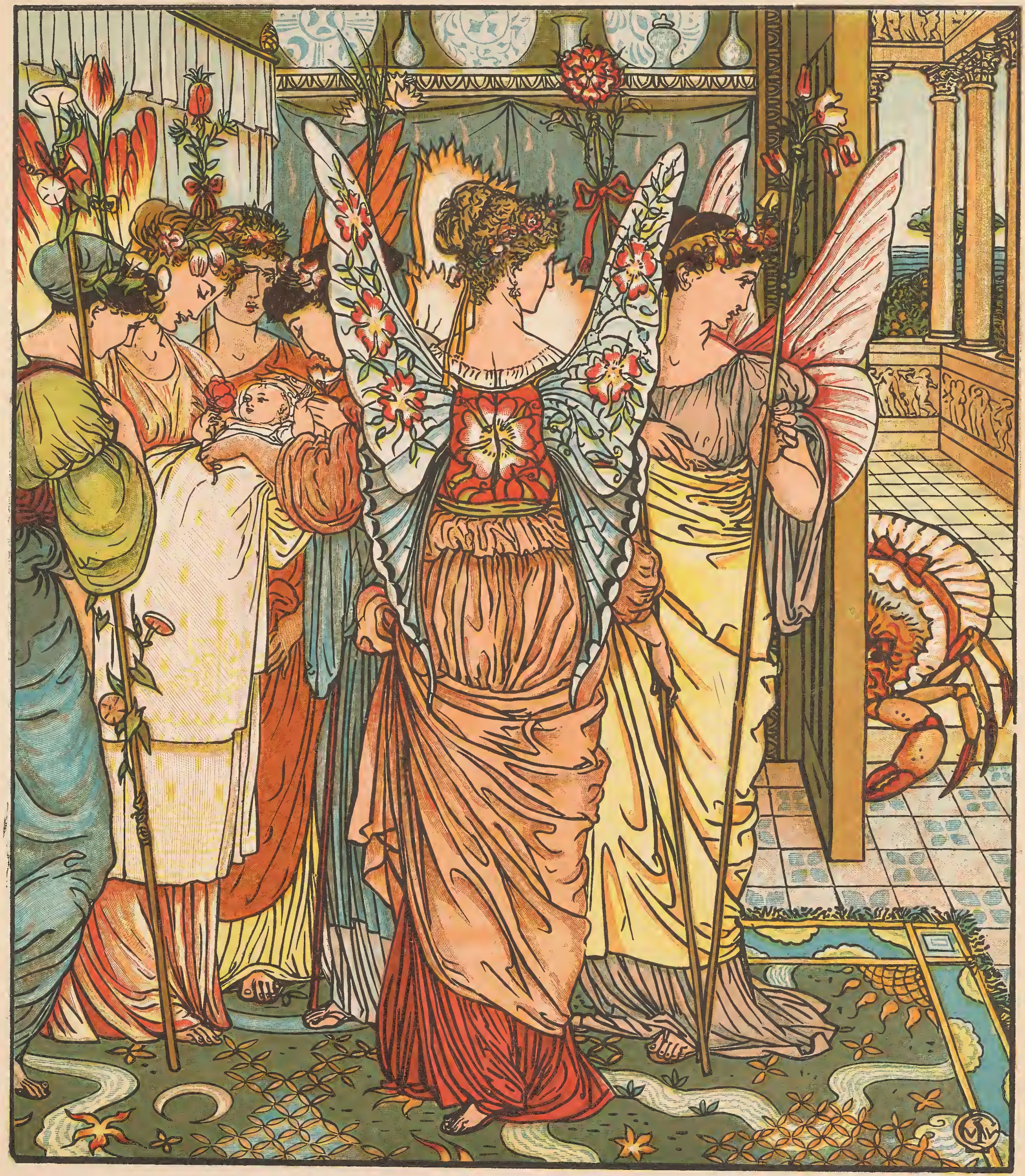





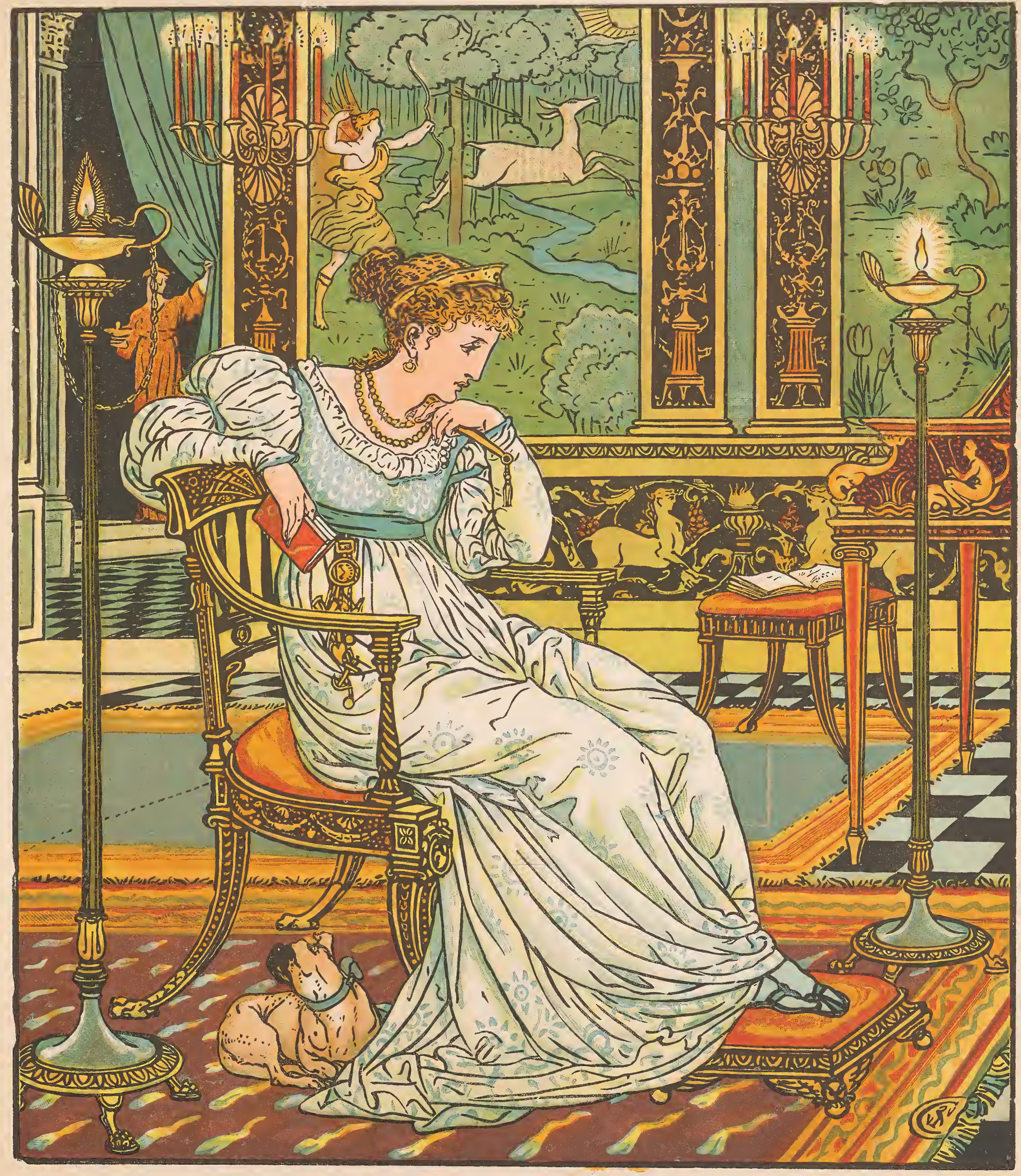



As soon as the crab had left, the Queen asked the fairies to preserve her daughter from the threatened evil, and they decided to build a palace without doors or windows, and to educate the Princess there till the fatal period should have expired. Three taps of a wand produced this grand edifice, in which there was no light but that of wax candles and lamps; but there were so many of these that it was as light as day. The Princess's intelligence and skill enabled her to learn very quickly, while her wit and beauty charmed everybody; the Queen would never have lost sight of her, if her duty had not obliged her to be near the King. The good fairies every now and then went to see the Princess. As the time drew near for her to leave the palace, the Queen had her portrait taken, and sent it to the greatest courts of the world. There was not a prince who did not admire it; but there was one who could never leave it. He shut himself up, and talked to it as though it could understand him. The King, who now hardly ever saw his son, inquired what prevented his appearing as cheerful as usual. Some courtiers told him they feared the Prince would go out of his mind; for he remained whole days shut up in his room, talking as though he had some lady with him. The King sent for his son, and asked him why he was so altered. The Prince threw himself at his father's feet, and said, "I confess that I am desperately in love with Princess Désirée, and wish to marry her." He ran for the portrait, and brought it to the King, who said, "Ah! my dear Guerrier, I consent to your wish.

hall become young again when I have so lovely a Princess at my court."

The Prince begged the King to send an ambassador to Princess Désirée; and Becafigue, a very eloquent young nobleman, was selected.

The ambassador took his leave of the Prince, who said, "Remember, my dear Becafigue, that my life depends upon this marriage. Omit no means of bringing the lovely Princess back with you."

The ambassador took with him many presents for the Princess, and also a portrait of the Prince.

On his arrival, the King and Queen were enchanted; they had heard of Prince Guerrier's personal merits, and were well content to have found a husband for their daughter so worthy of her.

The King and Queen resolved that the ambassador should see Désirée, but the Fairy Tulip said to the Queen, "Take care, Madam, that you do not introduce Becafigue to the Princess; he must not see her yet, and do not consent to let her go until she is fifteen years old; for if she quit her palace before then some misfortune will befall her." And the Queen promised to follow her advice.

On the ambassador's arrival, he asked to see the Princess, and was surprised that that favour was denied him. "It is no caprice of ours, my Lord Becafigue," 
said the King, "that induces us to refuse a request which you are perfectly justified in making;" and he then related to the ambassador the Princess's extraordinary adventure.

The Queen had not yet spoken to her daughter of what was passing; but the Princess knew a great marriage was in agitation for her.

The ambassador, finding his endeavours to obtain the Princess were useless, took leave of the King, and returned. When the Prince found he could not hope to see his dear Désirée for more than three months, he fell dangerously ill. The King was in despair, and resolved to go to the father and mother of Désiree, and entreat them no longer to defer the marriage.

During all this time Désirée had scarcely less pleasure in looking at the Prince's portrait than he had in gazing at hers. And her attendants did not fail to discover this-amongst others, Giroflée and Longue-épine, her maids of honour. Giroflée loved her dearly, and was faithful; but Longue-épine had always nourished a secret jealousy of her. Her mother had been the Princess's governess, and was now her principal lady-in-waiting, but as she doted on her own daughter, she could not wish well to Désirée.

The ambassador Becafigue again posted with the greatest speed to the city where Désirée's father resided, and assured the King and Queen that Prince Guerrier would die if they refused him their daughter any longer. At last they promised him that before evening he should know what could be done in the matter. The Queen went to her daughter's palace, and told her all that had passed. Désirée's grief was very great, but the Queen said, "Do not distress yourself, my dear child; you are able to cure him. I am only uneasy on account of the threats of the Fairy of the Fountain." "Could I not go in a coach," replied she, "so closely shut up that I could not see daylight? They might open it at night, to give me something to eat, and I should thus arrive safely at the palace of Prince Guerrier."

The King and Queen fancied this expedient very much; and they sent for Becafigue, telling him the Princess should set out instantly. The ambassador thanked their Majesties, and again returned to the Prince.

A coach was built, lined with pink and silver brocade. There were no glass winciows in it; and one of the first noblemen in the kingdom had charge of the keys. And Désirée was locked up in the coach, with her principal ladyin-waiting, Longue-épine, and Giroflée. Longue-épine did not like the Princess; and was in love with Prince Guerrier, whose likeness she had seen. When upon the point of setting out she told her mother she should die if the Princess's marriage took place; and the lady-in-waiting said she would endeavour to prevent it.

The. King and Queen felt no uneasiness for their daughter; but Longue- 


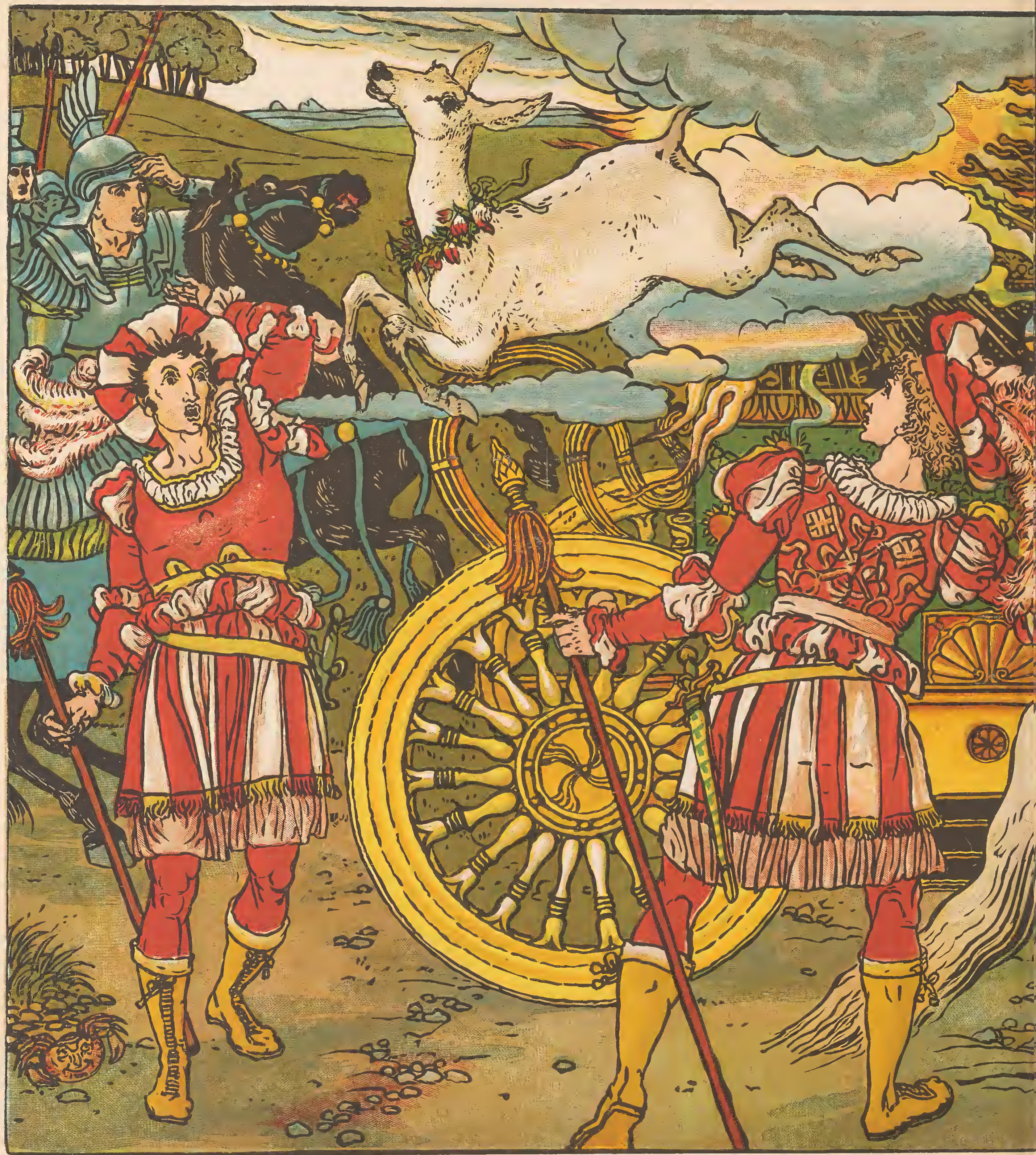




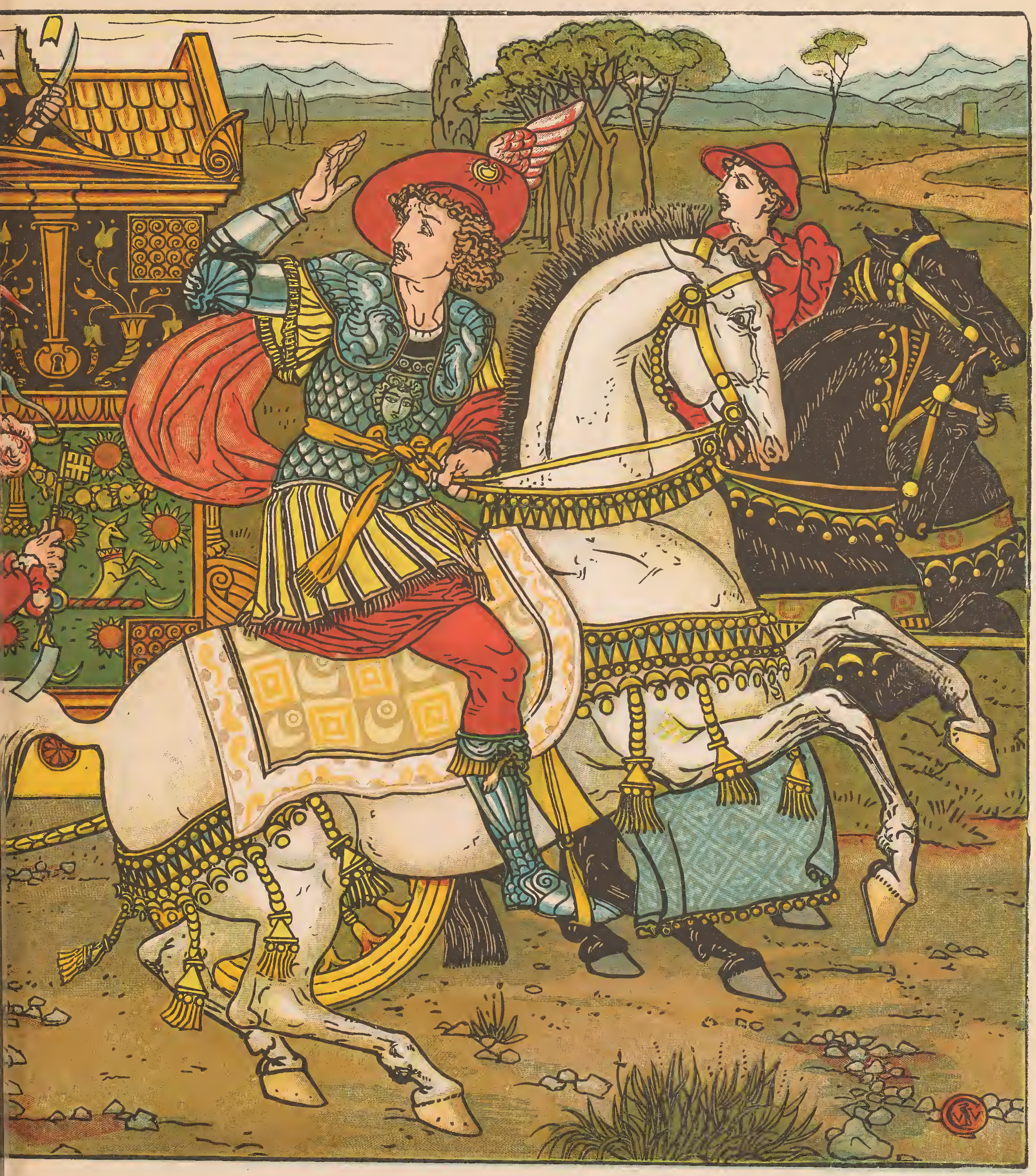



épine, who learned each night from the Princess's officers the progress they were making, urged her mother to execute her plans. So about midday, when the sun's rays were at their height, she suddenly cut the roof of the coach with a large knife. Then, for the first time, Princess Désirée saw the light of day. She had scarcely looked at it, and heaved a deep sigh, when she sprang from the coach in the form of a White Hind, and bounded off to the forest, where she hid herself in a dark covert.

The Fairy of the Fountain, who had brought about this event, seemed bent on the destruction of the world. Thunder and lightning terrified the boldest, and no one remained but the lady-in-waiting, Longue-épine, and Giroflée, the latter of whom ran after her mistress. The two others lost not a moment in executing their project. Longue-épine dressed herself in Désirée's richest apparel, and followed by her mother, set forth towards the city, and were met by the King and his son. The King, advancing with all his court, joined the false Princess; but the moment he saw her, he gave a cry, and fell back. "What do I see ?" said he. "Sire," said the lady-in-waiting, boldly advancing, "this is the Princess Désirée, with letters from the King and Queen. I also deliver into your hands the casket of jewels which they gave me on setting out."

The King heard this in sullen silence, and the Prince, leaning upon Becafigue, approached Longue-épine, who was as ugly as Désirée was beautiful.

Struck with astonishment, "I am betrayed," cried he, addressing himself to the King. "What mean you, my lord?" said Longue-épine; "know that you will never be deceived in marrying me." The King and Prince did not answer her; they each remounted their litters, one of the body-guards placed the sham Princess behind him, and the lady-in-waiting was similarly treated; they were then carried into the city, and were shut up in a castle.

Prince Guerrier was so overwhelmed by the shock that he could no longer endure the court, and determined to leave it secretly, to seek out some solitary place wherein to pass the remainder of his sad life. He communicated his plan to Becafigue; who, he felt persuaded, would follow him anywhere. $\mathrm{He}$ left upon his table a long letter for the King, assuring him that the moment his mind was more at ease he would return.

While everybody endeavoured to console the King, the Prince and Becafigue sped away, and at the end of three days found themselves in a vast forest, where the Prince, who was still ill, dismounted, while Becafigue went to seek for some fruits for their refreshment.

It is a long time since we left the Hind in the Wood. The Fairy Tulip felt for her misfortune; and conducted Giroflée towards the forest, that she might consolc the Princess. Giroflée was looking for her dear mistress, when the hind saw her, and leaping a brook, ran up eagerly and caressed her a thousand 


\section{The Hind in the Wood.}

times. Giroffee looked at it earnestly, and could not doubt that it was her dear Princess. Their tears affected the Fairy Tulip, who suddenly appeared. Giroflée entreated her to restore Désirée to her natural form. "I cannot do that," said Tulip; "but I can shorten her term of punishment; and to soften it, as soon as day gives place to night, she shall quit the form of a hind-but, as soon as it is dawn, she must return to it, and roam the plains and forests like the other animals."

"Proceed by this path," continued she, "and you will come to a little hut." So saying, she disappeared. Giroflée followed her directions, and found an old woman seated upon the step of the door finishing an osier basket. She led them into a very pretty room, in which were two little beds. As soon as it was quite dark, Désirée ceased to be a hind: she embraced Giroflée, and promised that she would reward her the moment her penance had ended. The old woman knocked at their door, and gave them some fruit. They then went to bed, and as soon as daylight appeared, Désirée, having become a hind again, plunged into the wood. Meanwhile Becafigue arrived at the cottage and asked the old woman for several things his master wanted. She filled a basket for him, and offered them shelter for the night, which was accepted.

The Prince slept restlessly, and as soon as it was day he arose and went into the forest. After he had walked for some time a hind started off, and he let fly an arrow at her. This hind was no other than Désirée, but her friend Tulip preserved her from being struck. She felt very tired, as such exercise was quite new to her. At last the Prince lost sight of her, and being fatigued himself, gave up the pursuit.

The next day the Prince again went to the forest, determined that the hind should not escape him. He walked about for some time, and, being much heated, he lay down and fell into a sleep; and while he was sleeping the hind came to the spot. She crouched down a little distance from him and touched him, when he awoke. His surprise was great; she ran off with all her might, and he followed her. At length she could run no longer, and the Prince cane up to her with delight. He saw she had lost all her strength, so he cut some branches from the trees, covered them with moss, and placing her gently upon the boughs, sat down near her. She became very uneasy, however, as night approached. She was thinking how to escape, when the Prince left her to search for some water. While he was gone she stole away, and safely reached the cottage. The Prince returned as soon as he had found a spring, and sought her everywhere, but in vain; so he returned to the cottage and related to his friend the adventure with the hind, accusing her of ingratitude. Becafigue laughed, and advised him to punish her when he had the chance. Daylight returned, and the Princess resumed her form of the white hind, and 


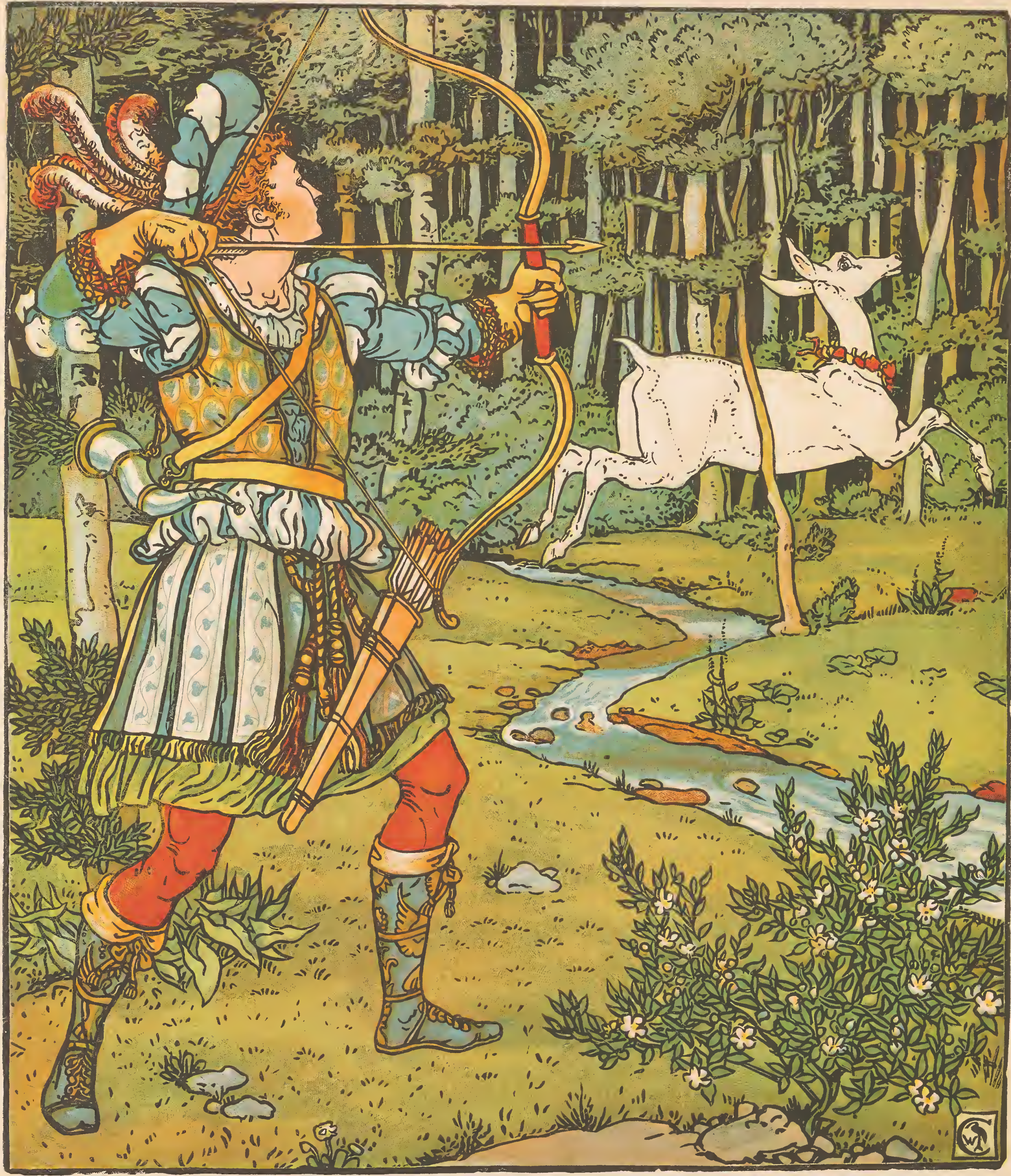





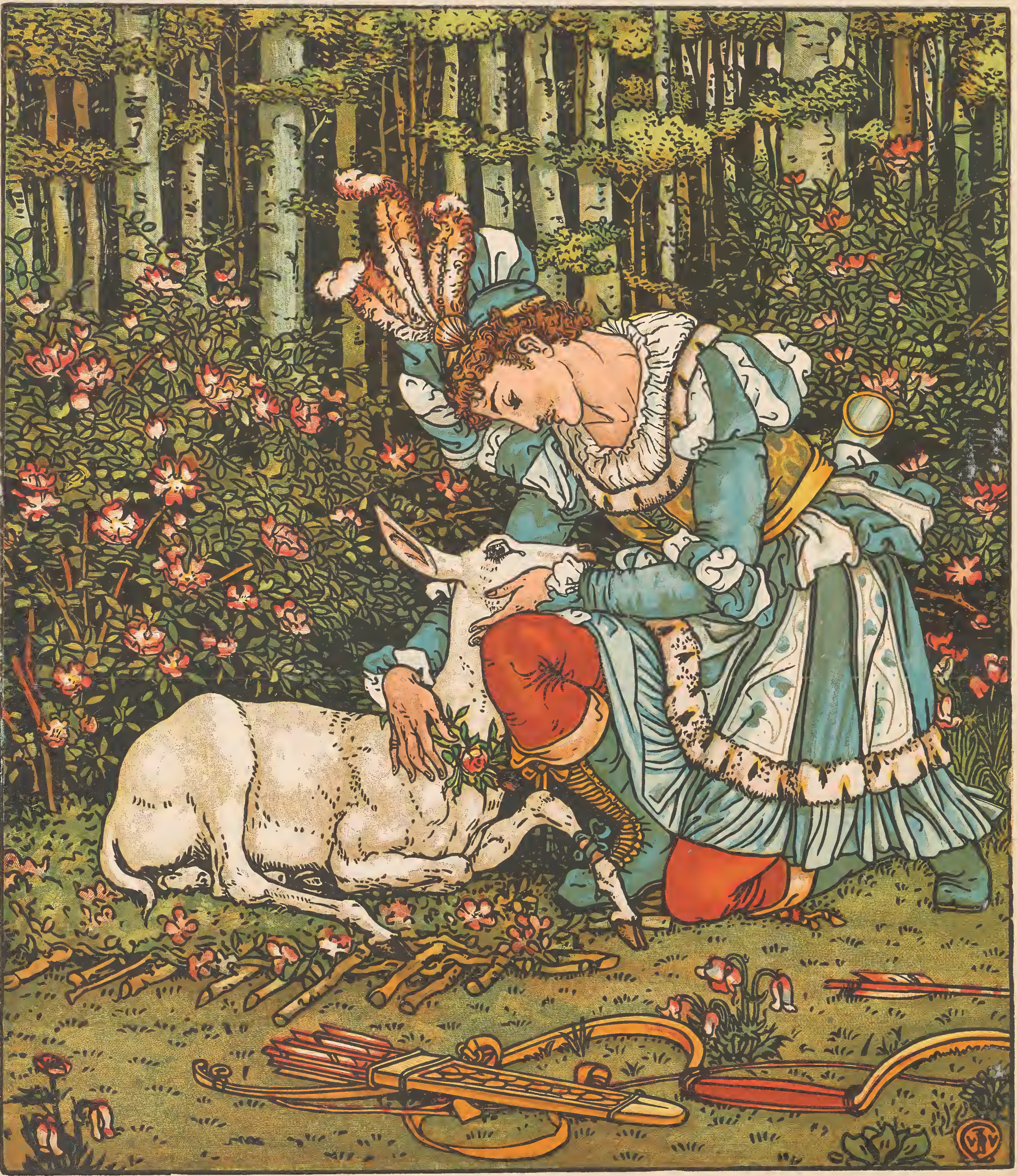




\section{The Hind in the Wood.}

hid herself far away in the forest. She was just fancying herself quite safe, when she caught sight of the Prince. She instantly fled, but as she was crossing a path, he lodged an arrow in her leg, when her strength failed her, and she fell. The Prince came up and was greatly grieved to see the hind bleeding. He gathered some herbs, bound them round her leg, and made her a new bed of branches. He placed the hind's head upon his knees, and lavished caresses upon her. At last the time arrived for returning to the old woman's ; he lifted up his game, but he felt that without assistance he could not get his captive home, so he bound her with ribands to the foot of a tree, and went to look for Becafigue. The hind tried in vain to escape, when Giroflée passed by the spot where she was struggling, and set her free just as the Prince and Becafigue arrived and claimed her. "My lord," replied Giroflée, "this hind belonged to me before she did to you. I would much sooner lose my life than her." Upon this the Prince generously gave her up.

They returned to the cottage, and the Prince went in shortly after and inquired who the young woman was. The old dame replied that she did not know; but Becafigue said he knew she had lived with Princess Désirée, and being determined to convince himself, he set to work and made a hole in the partition large enough to perceive them. Giroflée was binding up the Princess's arm, from which the blood was flowing. They both appeared much distressed. "Alas!" said the Princess, "must I become a hind every day, and see him to whom I am betrothed without being able to speak to him!" Becafigue was astonished. He ran for the Prince, who looked through the aperture, and immediately recognised the Princess. Without delay he knocked gently at the door, Giroflée opened it, and the Prince threw himself at the feet of Désirée.

"What!" exclaimed he, "is it you whom I wounded under the form of a white hind?" He was so afflicted that Désirée assured him it was a mere trifle; she spoke to him so kindly that he could not doubt her love for him. He was explaining in his turn the trick that Longue-épine and her mother had played him, when a shrill noise of trumpets echoed through the forest. The Prince looked out of the window and recognised his own colours and standards, and catching sight of his father's litter, ran to it, and told the King of his fortunate meeting with the real Princess.

All this was brought about by the Fairy Tulip. The pretty house in the wood was hers, and she herself was the old woman. The army was ordered to march back again. The Prince and Princess were received in the capital with shouts of joy; everything was prepared for the nuptials, which were rendered more solemn by the presence of the six fairies; and Becafigue was married to Giroflée at the same time. 



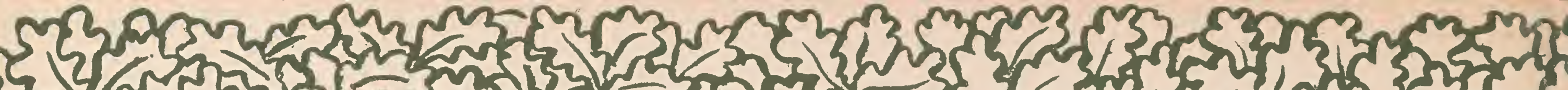

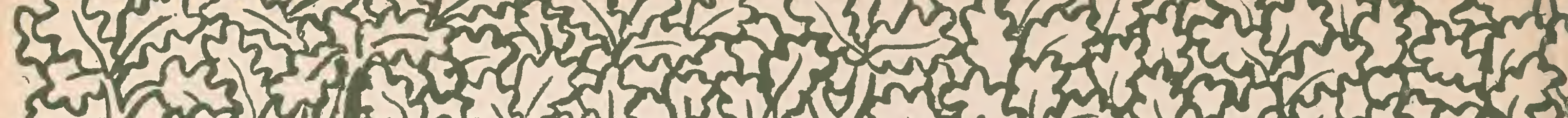

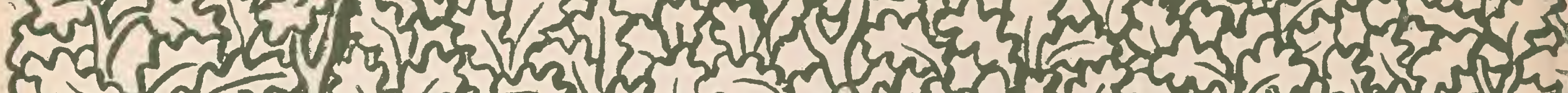

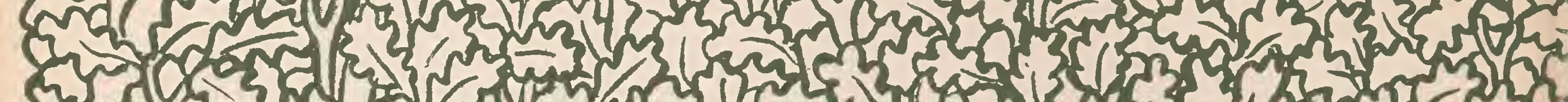

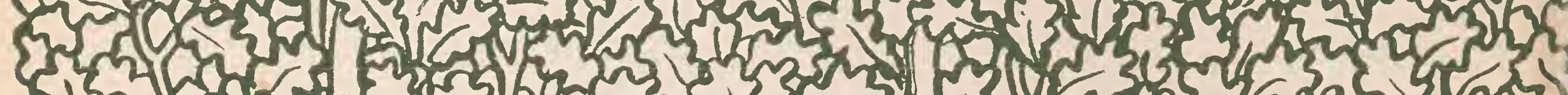

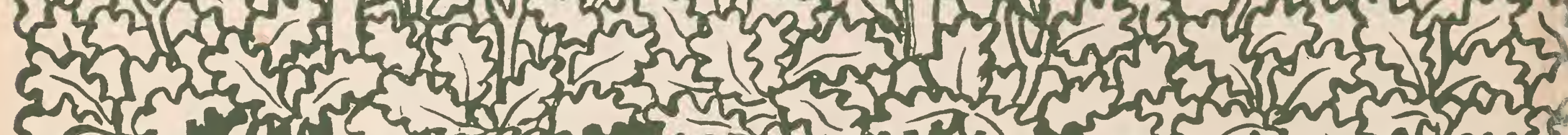

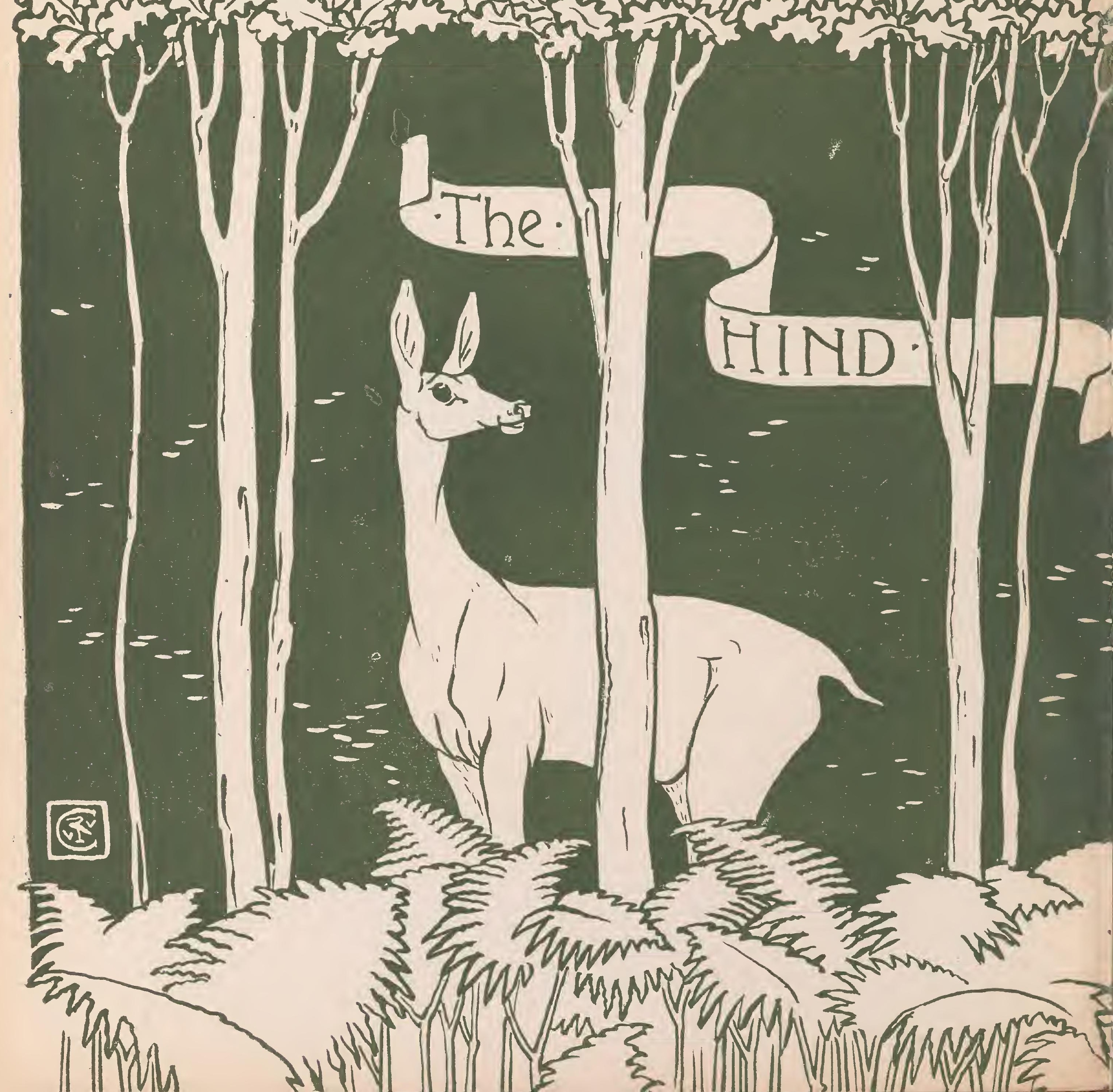



Nom - i ( ) 1) C.

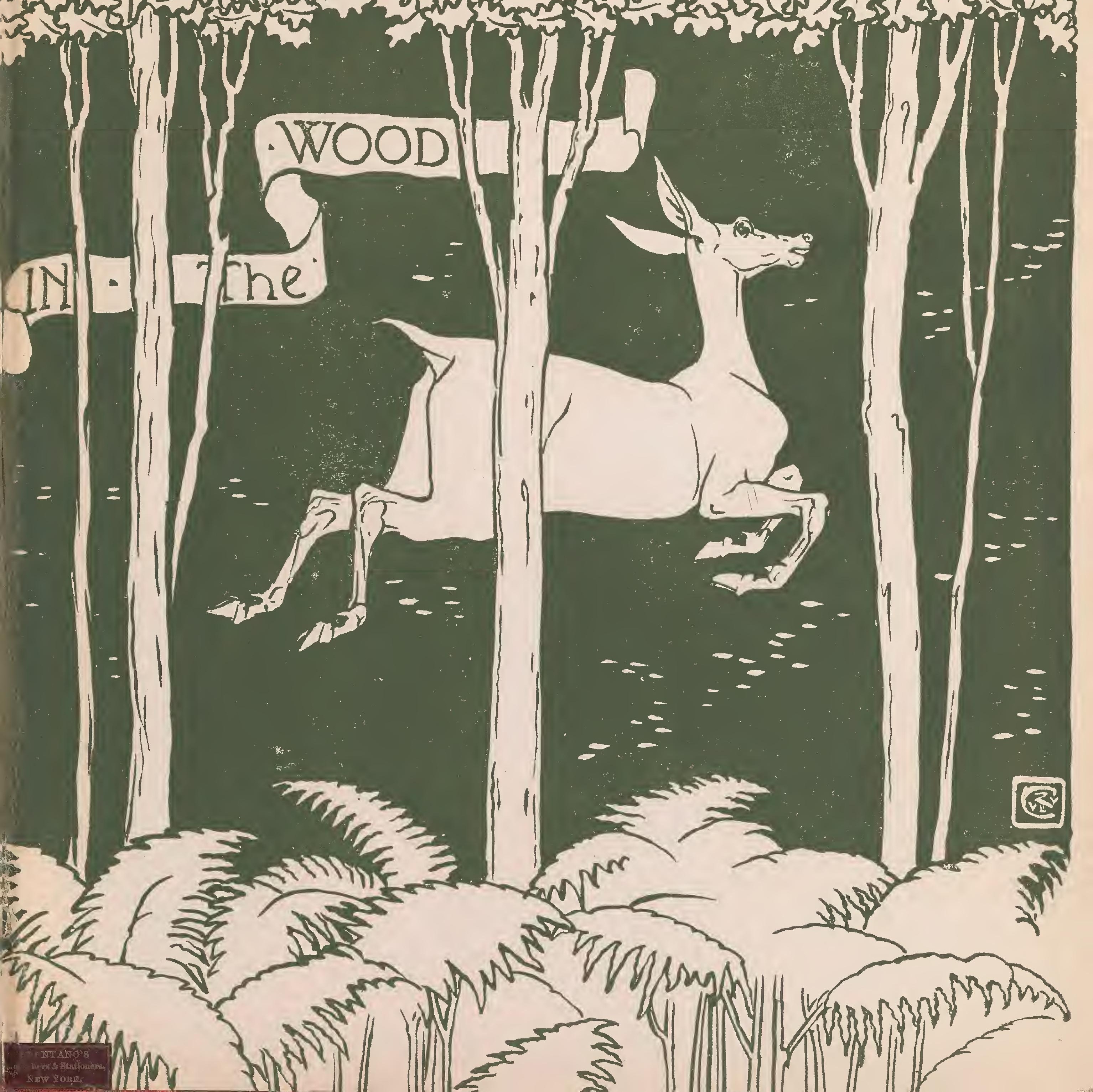


